\title{
SURVEY 2018: TEKNISK RAPPORT
}

\author{
Magnus Hagevi, Institution för statsvetenskap, Linnéuniversitet \\ E-post I magnus.hagevi@1nu.se
}

Surveyinstitutet vid Linnéuniversitetet har genomfört en frågeundersökning år 2018. Frågeundersökningen kallas för Survey 2018. Survey 2018 var speciellt inriktad på att undersöka medborgarna vid riksdagsvalet 2018: val av parti, personval, väljarnas övervägande i samband med val, ideologiska dimensioner, åsikter i enskilda politiska frågor, bedömning av ekonomi, populism samt en rad sociala faktorer som kan påverka röstning som social position (kön, ålder, uppväxtförhållande, yrke, urbaniseringsgrad, inkomst, utbildning, religiositet med mera). Denna artikel är en teknisk rapport av frågeundersökningen Survey 2018. Rapporten behandlar frågeformulär, fältarbetets uppläggning, population, urval och svarsfrekvens samt bortfallsanalys. Survey 2018 är den sjätte nationella frågeundersökningen som Surveyinstitutet har genomfört. De två tidigare är Survey 2009, Survey 2010, Survey 2012, Survey 2014 och Survey 2016 (för teknisk rapport om dessa, se Hagevi 2010, 2011, 2014, 2015, 2016). Survey 2018 har genomgått etikprövning och godkänts av Regionala etikprövningsnämnden i Linköping.

\section{Frågeformulär}

Till personerna i urvalet skickades ett frågeformulär på 12 sidor. De frågor som ingick i frågeformuläret behandlade värden och ideologi, valrörelsebeteende, röstning och partipreferens, uppfattning om de politiska partierna, politiska åsikter, uppfattning om ekonomi, politikerförtroende och populism, samt religiositet. Till dessa frågor tillkom så kallade bakgrundsfrågor som tog upp uppgifter som svarspersonen rörande kön, födelseår, 
uppväxtförhållanden, urbaniseringsgrad, klass och yrke, utbildning, utländsk bakgrund, inkomster och personliga inkomstförhållanden, samt nuvarande familjeförhållanden. Hela frågeformuläret redovisas i bilaga $1 \mathrm{i}$ form av en kodbok.

I tabell 1 redovisas dispositionen av innehållet i Survey 2018:s frågeformulär.

Tabell 1. Innehåll i Survey 2018

\begin{tabular}{ll}
\hline Frågenummer & Ämnesområde \\
\hline $1-9$ & Värderingar \\
$10-12$ & Valrörelsen \\
$13-33$ & Valet, röstning och politiska partier \\
$34-38$ & Ekonomi och politik \\
$41-49$ & Religion \\
50 & Olika politiska sakfrågor \\
$51-70$ & Social bakgrund och uppväxt \\
\hline
\end{tabular}

Frågeformuläret har utarbetats i samarbete mellan Surveyinstitutet och de deltagande forskningsprojekten. För att besvara frågorna kryssar svarspersonen i en ruta som indikerar det färdigformulerade svar som svarspersonen anser är lämpligast. Det finns ett fåtal möjligheter att komplettera med mycket kortfattade öppna svar.

\section{Frågeundersökningens genomförande}

Fältarbetet för Survey 2018 genomfördes av Kantar-Sifo (där Caroline Theorell och Malin Grundqvist ledde fältarbetet) under några månader i slutet av 2018. Den första kontakten med svarspersonerna skedde veckan före riksdagsvalet 9 september 2018 och sista svaret mottogs $i$ mitten av november 2018. Fältarbetet inleddes med att personerna i urvalet fick ett vykort med posten (vykortet skickades måndag 3 september). Syftet med vykortet var att informera personerna i urvalet att de blivit utvalda att ingå i Survey 2018. Fredag 7 september skickades frågeformuläret ut med post. Med frågeformuläret sändes också uppgifter som innebar att personerna i urvalet kunde svara på enkäten via Internet, en så kallad webbenkät.

Därefter vidtog en omfattande aktivitet för att få så många som möjligt av personerna i urvalet att svara på enkäten. Ett "tack- och påminnelsekort" skickades ut till personerna i urvalet tisdagen 18 september till samtliga personer i urvalet. Ett andra utskick med ännu ett enkätformulär sändes ut måndagen 1 oktober till de i urvalet som ännu inte besvarat Survey 2018. Även nu fick personerna i urvalet information om möjligheten att svara via webbenkät. Det tredje utskicket, även det med enkätformulär på Survey 2018 och med instruktion om möjligheten att svara via webbenkät, skickades till de kvarvarande i urvalet som inte svarat måndagen 15 oktober, vilket följdes upp med telefonpåminnelse (upp till fem kontaktförsök) till de som inte svarat (med start måndagen 5 november). Sista svaret noterades tisdag 20 november 2018 varefter datainsamlingen avslutades.

För att öka svarsfrekvensen erbjöds samtliga personer i urvalet som besvarade enkäten trisslotter. Efter fältperioden avslutats sändes tackbrev och trisslott till alla svarande. 


\section{Population, urval och svarsfrekvens}

Frågeundersökningen Survey 2018 genomfördes i form av en postenkät till ett obundet sannolikhetsurval. I urvalsramen ingick samtliga boende i Sverige i åldrarna 18 till 85 år. Inte enbart svenska medborgare ingick i undersökningen, utan även utländska medborgare. Urvalet bestod av 3000 personer. Efter att ha beaktat naturligt bortfall återstod 2958 personer i det så kallade nettourvalet. Andelen nettosvarande beräknades genom att beakta de frågeformulär som inte nådde fram till svarspersonen (bland annat på grund av att de avlidit, hade sjukdom som förhindrade svar, flyttat utan angiven svensk adress eller liknande skäl), så kallat naturligt bortfall. För de personer som ingick i urvalet är deltagande i undersökningen frivilligt.

När fältarbetet avslutades var andelen svarande 46,9 procent av hela urvalet, vilket var 1408 svar (se tabell 2). Om andelen svarande beräknas på nettourval är svarsandelen 48,2 procent.

Tabell 2. Svar och bortfall i Survey 2018.

\begin{tabular}{lr}
\hline Bruttourval & 3000 \\
Naturligt bortfall & 77 \\
Nettourval & 2923 \\
Antal svarsvägrare & 1515 \\
Antal svarande & 1408 \\
Andel nettosvar (i procent) & 46,9 \\
Andel svarande (i procent) & 48,2 \\
\hline
\end{tabular}

I kategorin svarsvägrare ingår de personer som på eget initiativ meddelat att de ej vill delta i undersökningen och de som inte deltagit i undersökningen utan att meddela detta (ej anträffade).

I figur 1 redovisas den kumulativa nivån av de besvarade enkäterna under fältarbetet.

Enligt sammanställningen i figur 1 har de flesta svarspersoner sänt in enkäten tidigt under fältperioden. Av den totala andelen besvarade enkäter i Survey 2018 hade 66 procent kommit in redan den första 14-dagarsperioden i september. Första oktober, när andra påminnelsen gick ut, hade ytterligare 11 procentenheter av det totala antalet svarande Survey 2018, det vill säga 75 procent av det totala antalet svarande. Då sista skriftliga påminnelsen gick ut, 15 oktober, hade nästan 90 procent av de svarande besvarat Survey 2018. När fältarbetet inledde de sista kontakterna genom telefonsamtal 5 november hade 97 procent av alla svarande registrerats. Efter telefonkontakt svarade de sista 3 procenten. Tiden när påminnelserna postades till urvalet är markerade med kryss i figur 1. Förutom de första två påminnelserna är effekten av påminnelser förhållandevis måttlig, något som framkommit under senare undersökningar från Surveyinstitutet. 
Figur 1. Kumulativt inflöde av samtliga enkäter i Survey 2018 (procent av samtliga svar).

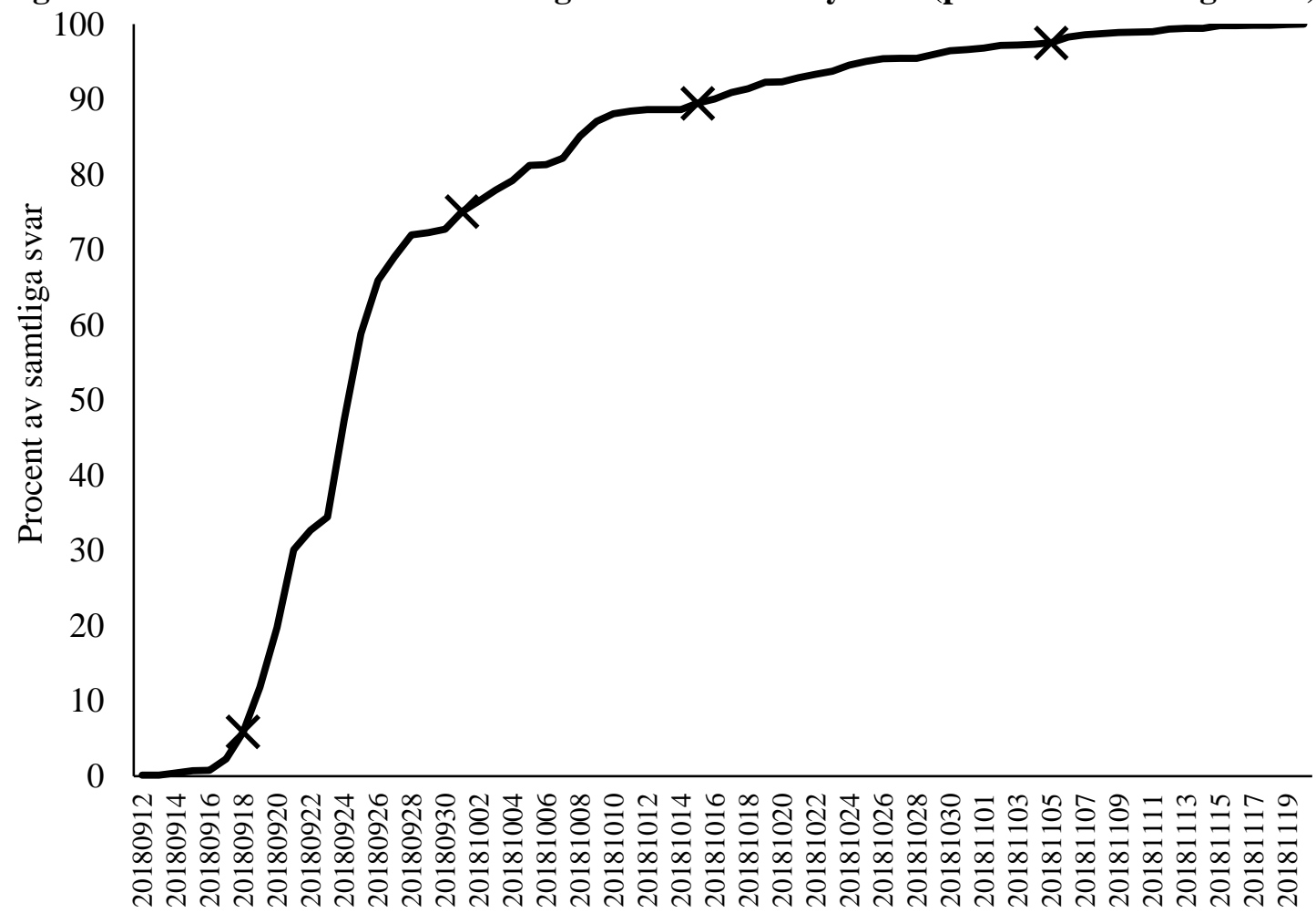

Kommentar: Kryssen markerar datum då påminnelser gick ut till urvalet.

Personerna i urvalet hade möjlighet att besvara enkäten med post (postal enkät) eller Internet (webbenkät). I figur 2 presenteras inflödet av postal enkät respektive webbenkät i form av antal svar.

Av figur 2 framgår att de flesta svarande använt postal enkät. Av samtliga svarande brukade 74,4 procent alternativet att besvara enkäten via post och 26,6 procent använde sig av webbenkäten. Bland dem som svarade med webbenkät var det aningen vanligare att svara tidigt (66.4 procent av användarna av webbenkät hade besvarat Survey 2018 under den första 14-dagarsperioden i september) än vad som var fallet bland personer som besvarat via enkätformuläret och skickat tillbaka det med post (65,7 procent av användarna av postal enkät hade besvarat Survey 2018 motsvarande period i september). Jämfört med tidigare undersökningarna har denna skillnad minskat betydligt, då det i tidigare undersökningar varit vanligare att svarspersonerna som använde webbenkät i större utsträckning skickade in sina enkätformulär tidigt. 
Figur 2. Kumulativt inflöde av postala- och webbenkäter i Survey 2018 (antal besvarade enkäter).

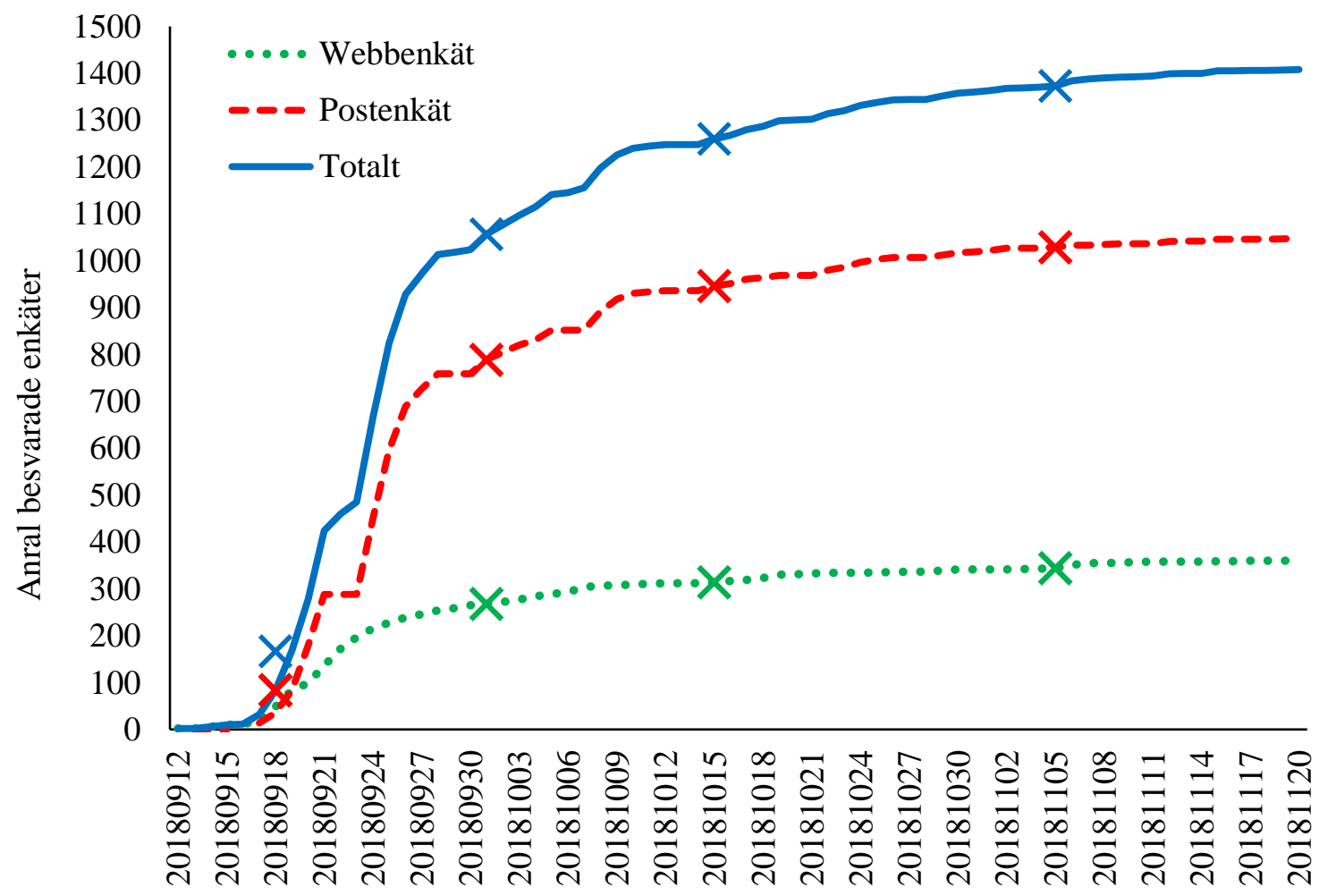

Kommentar: Kryssen markerar datum då påminnelser gick ut till urvalet.

Tiden när påminnelserna postades till urvalet är markerade med kryss i figur 2. Av figur 2 framgår att påminnelserna främst påverkade inflödet av svar genom användandet av postenkäter.

Av figur 3 framgår återigen att de flesta personer som besvarat Survey 2018 har gjort detta tidigt under fältarbetsperioden. Efter det att påminnelser skickats till de svarande har fler svar skickats in, dock med en avtagande verkan allt eftersom undersökningen fortgår. Undantaget sista påminnelsen (där inget pappersformulär skickades ut) är det framförallt postala enkäter som svarspersonerna använder efter påminnelser. 
Figur 3. Veckovis inflöde av samtliga enkäter i Survey 2018 (antal besvarade enkäter).

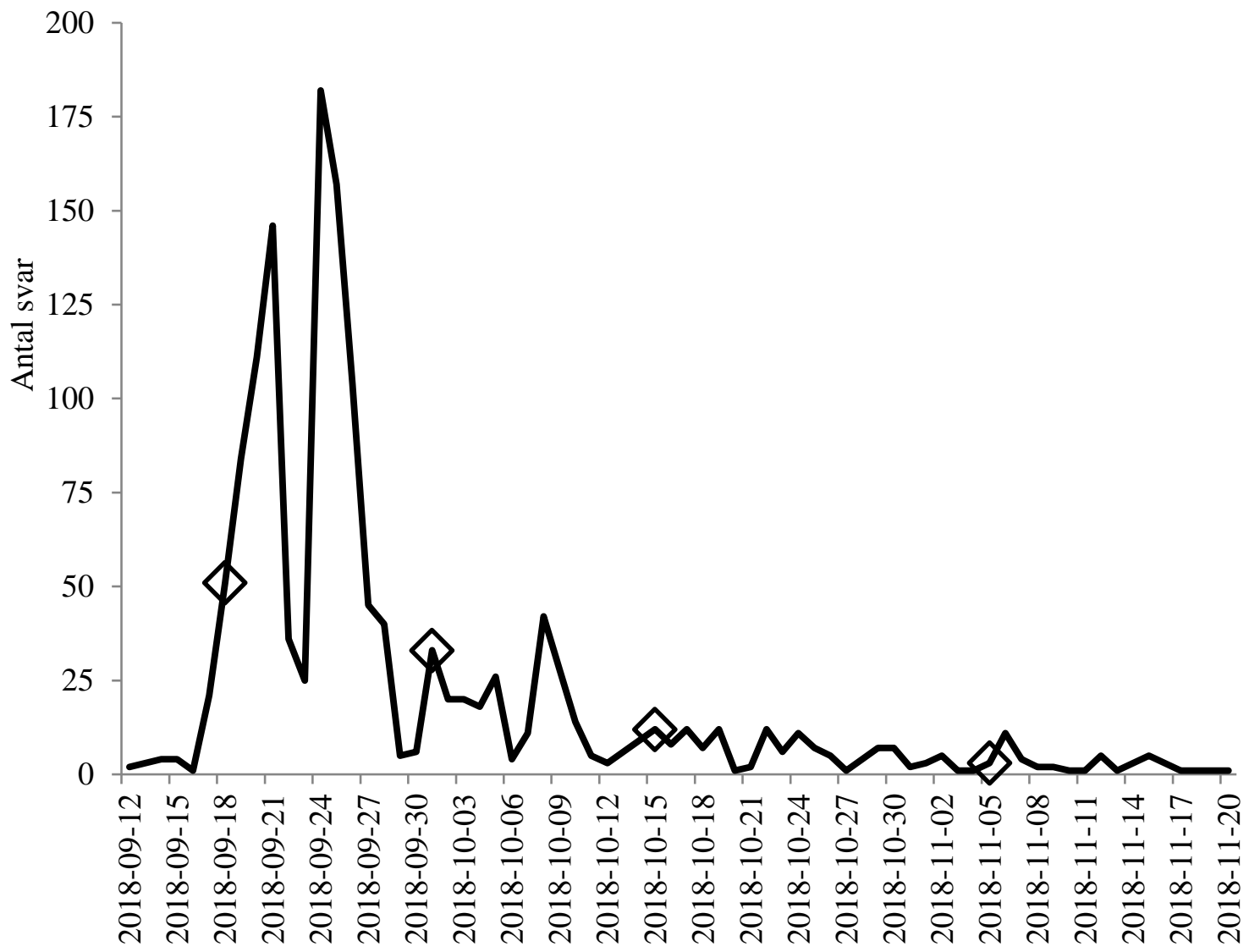

Kommentar: Romberna markerar datum då påminnelser gick ut till urvalet.

\section{Bortfallsanalys: kön, ålder och region}

Bortfall sker inte slumpvis. Beroende på personliga egenskaper skiftar benägenheten att besvara enkäter. Detta kan påverka undersökningens representativitet. Personer med gemensamma egenskaper kan till exempel ha liknande åsikter som skiljer sig från andra personer med andra egenskaper. Om en grupp med likartade och avvikande åsikter dessutom tenderar att inte besvara enkäten i större utsträckning än andra minskar undersökningens representativitet (Hagevi och Viscovi 2016). Ett sätt att kontrollera om bortfallet kan påverka representativiteten är att undersöka i vad mån andelen svarande skiftar beroende på olika egenskaper hos personerna $\mathrm{i}$ urvalet. I Survey 2018 är det möjligt att genomföra en bortfallsanalys utifrån kön, ålder och region (se tabell 3).

Svarsandelen varierar något mellan olika regioner. Flest andel svar kommer från Mellersta och Övre Norrland samt minst andel svar från Stockholms län. För övriga regioner är variationen $\mathrm{i}$ andelen svarande relativt liten. Det är en större andel av kvinnorna i urvalet som besvarat enkäten än vad det är män. Äldre besvarar oftare Survey 2018 än yngre. Tendensen att svarsandelen ökar 
bland personer som är över 60 år. I ålderskategorin 66-75 år har speciellt många besvarat undersökningen. Andelen svarande bland personer som är 18-25 år är dock mycket låg.

Tabell 3. Andel svarande av bruttourvalet (3000 personer) efter kön, ålder och region (procent).

\begin{tabular}{|c|c|c|}
\hline Kön & $\begin{array}{l}\text { Kvinnor } \\
\text { Män }\end{array}$ & $\begin{array}{l}49 \\
45\end{array}$ \\
\hline Ålder & $\begin{array}{l}18-25 \stackrel{a r}{ } \\
26-30 \stackrel{\circ}{r} \\
31-40 \stackrel{\circ}{a r} \\
41-50 \stackrel{\circ}{ } \\
51-60 \stackrel{\circ}{r} \\
61-65 \stackrel{\circ}{\circ} \\
66-75 \stackrel{\circ}{r} \\
76-85 \stackrel{a}{a r}\end{array}$ & $\begin{array}{l}25 \\
34 \\
41 \\
44 \\
48 \\
61 \\
65 \\
60\end{array}$ \\
\hline Region & $\begin{array}{l}\text { Stockholms län } \\
\text { Östra Mellansverige } \\
\text { Småland med öarna } \\
\text { Sydsverige } \\
\text { Västsverige } \\
\text { Norra Mellansverige } \\
\text { Mellersta Norrland } \\
\text { Övre Norrland }\end{array}$ & $\begin{array}{l}43 \\
48 \\
48 \\
49 \\
46 \\
48 \\
55 \\
52 \\
\end{array}$ \\
\hline Samtliga & & 47 \\
\hline
\end{tabular}

\section{Svarspersonernas representativitet}

Avsikten med Survey 2018 är att de svarande skall vara representativa med svenska befolkningen mellan 18 och 85 år. I den mån det finns avvikelser mellan kända egenskaper i den svenska befolkningen och svarspersonerna - de personer i urvalet som besvarat och skickat tillbaka frågeformulären - i Survey 2018 visar det på minskad representativitet mellan population och svarspersonerna i urvalet. I tabell 4 redovisas svarspersonernas sammansättning beträffande kön, ålder och region. Denna fördelning i urvalet jämförs med sammansättningen i den svenska befolkningen. Data för svenska befolkningen i åldersintervallet 18-85 år har hämtats från Statistiska centralbyrån (SCB). 
Tabell 4. Urval- och svarspersonernas fördelning angående kön, ålder, region och medborgarskap i jämförelse med svenska befolkningen (procent).

\begin{tabular}{|c|c|c|c|c|c|c|}
\hline & & $\begin{array}{c}\text { Urval i } \\
\text { Survey } \\
2018\end{array}$ & $\begin{array}{c}\text { Svarande i } \\
\text { Survey } \\
2018\end{array}$ & $\begin{array}{l}\text { Svenska } \\
\text { befolk- } \\
\text { ningen }\end{array}$ & $\begin{array}{c}\text { Differens } \\
\text { urval- } \\
\text { befolkn. }\end{array}$ & $\begin{array}{c}\text { Differens } \\
\text { svarande- } \\
\text { befolkn. }\end{array}$ \\
\hline \multirow{2}{*}{ Kön } & Kvinnor & 49 & 50 & 50 & -1 & 0 \\
\hline & Män & 51 & 50 & 50 & +1 & 0 \\
\hline \multirow[t]{8}{*}{ Ålder } & $18-25 \stackrel{a}{\mathrm{r}}$ & 11 & 6 & 12 & -1 & -5 \\
\hline & $26-30 \stackrel{a}{\mathrm{r}}$ & 9 & 7 & 10 & -1 & -3 \\
\hline & $31-40 \stackrel{\circ}{\mathrm{r}} \mathrm{r}$ & 16 & 14 & 17 & -1 & -1 \\
\hline & $41-50 \stackrel{\mathrm{a} r}{ }$ & 17 & 16 & 17 & 0 & 0 \\
\hline & $51-60 \stackrel{a}{\mathrm{r}}$ & 16 & 17 & 16 & 0 & 0 \\
\hline & $61-65 \stackrel{a}{a}$ & 7 & 9 & 7 & 0 & 0 \\
\hline & $66-75 \stackrel{\circ}{a} r$ & 15 & 21 & 14 & +1 & +7 \\
\hline & 76-85 $\stackrel{a}{r}$ & 9 & 11 & 8 & +1 & +3 \\
\hline \multirow[t]{8}{*}{ Region } & Stockholms län & 23 & 21 & 23 & 0 & -2 \\
\hline & Östra Mellansverige & 17 & 18 & 17 & 0 & +1 \\
\hline & Småland med öarna & 9 & 9 & 8 & +1 & +1 \\
\hline & Sydsverige & 14 & 15 & 15 & -1 & 0 \\
\hline & Västsverige & 18 & 18 & 20 & -2 & -2 \\
\hline & Norra Mellansverige & 9 & 8 & 8 & +1 & 0 \\
\hline & Mellersta Norrland & 3 & 4 & 4 & -1 & 0 \\
\hline & Övre Norrland & 5 & 6 & 5 & 0 & +1 \\
\hline
\end{tabular}

Kommentar: På grund av avrundning till heltal summeras svenska befolkningens fördelning på ålder och regioner inte till 100 procent.

De regionala skillnaderna som finns mellan svarspersonerna i Survey 2018 och svenska befolkningen är små. Det samma gäller kön. För ålder är representativiteten delvis sämre. I den yngsta åldersgruppen 18-25 år är andelen av de svarande mindre än i svenska befolkningen medan i åldersgruppen 66-75 år är andelen av de svarande större än i svenska befolkningen. En lägre svarsfrekvens i den yngsta ålderskategorin än andra åldersgrupper förekommer ofta i liknande frågeundersökningar (Vernersdotter 2016). I övriga åldersgrupper är skillnaderna mindre. Förutom åldersgrupperna 18-25 år och 66-75 år visar resultatet på att frågeundersökningen Survey 2018 har god representativitet.

Problem med sviktande svarsandelar som har samband med olika demografiska faktorer (bland annat kön, ålder och region) har undersökts av Elias Markstedt (2012). Huvudresultatet visar att minskad svarsandel endast marginellt förändrar svarsfördelningen på enkätfrågor av den typ som används i Survey 2018.

Den sannolikt mest omfattande skevheten som blir resultatet av bortfallet analyseras dock inte i tabell 4. Troligtvis återfinns personer med lågt politiskt intresse i större utsträckning i bortfallet än personer som är mer intresserade av politik. Anledningen till ett sådant bortfall är att Survey 2018 till stor del är inriktad på politiska frågor, vilket främst bör attrahera politisk intresserade att besvara undersökningen. I frågeundersökningar som genomförts av Surveyinstitutet finns vissa möjligheter att undersöka effekten av bortfallet som har sitt ursprung i lågt politiskt intresse 
(Hagevi 2011, 2015). Survey 2010 och Survey 2014 genomfördes både strax efter riksdagsvalen dessa år. Största noterade skevheten i de båda frågeundersökningarna rörde en politisk aktivitet: deltagande i riksdagsvalen bland röstberättigade svarspersoner. I Survey 2010 uppgav 9 procentenheter fler att de röstat i riksdagsvalet jämfört med den faktiska röstandelen $\mathrm{i}$ riksdagsvalet. I Survey 2014 hade motsvarande skillnad i uppmätt och verkligt valdeltagande ökat till 11 procentenheter. I Survey 2018 uppgav knappt 8 procentenheter fler att de röstat i riksdagsvalet jämfört med den faktiska röstandelen i riksdagsvalet (Valmyndigheten 2020).

Det kan finnas flera orsaker till överrepresentationen av andelen röstande i Survey 2010, 2014 och 2018, en av dem torde vara skevt bortfall. ${ }^{1}$ Eftersom politiskt intresserade också röstar i större utsträckning än personer som är mer ointresserade av politik är det möjligt att överrepresentationen av röstande är ett resultat av att det är vanligare att politiskt intresserade personer besvarat Survey 2010, 2014 och 2018 än vad det är att relativt politiskt ointresserade personer gjort det samma. I Survey 2018 framgår det att andelen som själva uppfattar sig vara mycket eller ganska mycket intresserade av politik är större bland dem som också säger att de röstade i riksdagsvalet (63 procent, $n=1242$ ) än bland dem som besvarat Survey 2018 utan att ha röstat i riksdagsvalet trots att de hade rösträtt ( 38 procent, $n=34$ ). Dessa uppgifter liknar tidigare undersökningar som genomförts av Surveyinstitutet (Hagevi 2011: 346). Eftersom politiskt intresserade också röstar i större utsträckning än personer som är mindre intresserade av politik är det möjligt att andelen personer i urvalet som besvarade Survey 2010, 2014 och 2018 är större bland dem röstande i riksdagsvalen än dem som inte deltog i detta val. Valdeltagande uppmäts därför som högre i Survey 2010, 2014 och 2018 jämfört med riksdagsvalen. När politisk aktivitet undersöks i Survey 2018 är det därför sannolikt att den politiskt aktiva andelen är överrepresenterad i jämförelse med motsvarande andel i den svenska befolkningen. I exemplet med röstande i riksdagsvalet 2018 är överskattningen ungefär 9 procent $(87 \cdot 1,09 \approx 95)$.

\section{Sammanfattning}

Survey 2018 är en omfattande undersökning som beaktar en bred spektra av politiska frågor och förhållanden i det svenska samhället. Därmed finns det goda möjligheter att genomföra flera intressanta analyser av svenska befolkningen med Survey 2018. Analyser av datamaterialet bör dock beakta en viss sannolik överskattning i nivån av politiskt intresse och deltagande, att unga är underrepresenterade och personer i ålder 66-75 år överrepresenterade. Om detta beaktas är de data som samlats in genom Survey 2018 en god bas för att genomföra analyser av befolkningen i det svenska samhället. 


\section{Noter}

${ }^{1}$ Det finns även andra möjliga förklaringar till att valdeltagandet i Survey 2010, 2014 och 2018 skiljer sig från den faktiska andelen röstande. Svarspersonerna kan ha glömt om de röstat eller inte. Det är också möjligt att svarspersonerna uppfattar att det är svårt att etiskt försvara röstskolk, varför de kan uppge att de röstat även om så inte varit fallet.

\section{Referenser}

Hagevi, Magnus (2010): "Survey 2009: Teknisk rapport” i Avstamp: Svenska folkets värden och syn på brännande samhällsfrågor, red Magnus Hagevi. Växjö: Linnaeus University Press, s 193-227.

Hagevi, Magnus (2011): "Bildaga: Survey 2010” i Den svenska väljaren, red Magnus Hagevi. Umeå: Boréa förlag, s 339-360.

Hagevi, Magnus (2014): ’Survey 2012: Teknisk rapport”, Surveyjournalen, 1 (1): 59-67.

Hagevi, Magnus (2015): "Survey 2014: Teknisk rapport", Surveyjournalen, 2 (1-2): 125-132.

Hagevi, Magnus (2016): "Survey 2016: Teknisk rapport", Surveyjournalen, 2016, 3 (2): 20-29.

Hagevi, Magnus och Dino Viscovi (2016): Enkäter: Att formulera frågor och svar. Lund:

Studentlitteratur.

Markstedt, Elias (2012): Representativitet och viktning: Riks-SOM som spegel av det svenska samhället 1986-2011 (SOM-rapport 2012: 30). Göteborg: SOM-institutet, Göteborgs universitet.

Valmyndigheten (2020): Valresultat 2018 (internet: https://www.val.se/valresultat/riksdag-region-ochkommun/2018/valresultat.html, hämtad 2020-12-19).

Vernersdotter, Frida (2016). "Den nationella SOM-undersökningen 2015” i Ekvilibrium, red Jonas Ohlsson, Henrik Oscarsson och Maria Solevid, Göteborg: SOM-institutet, Göteborgs universitet, s 433 459. 

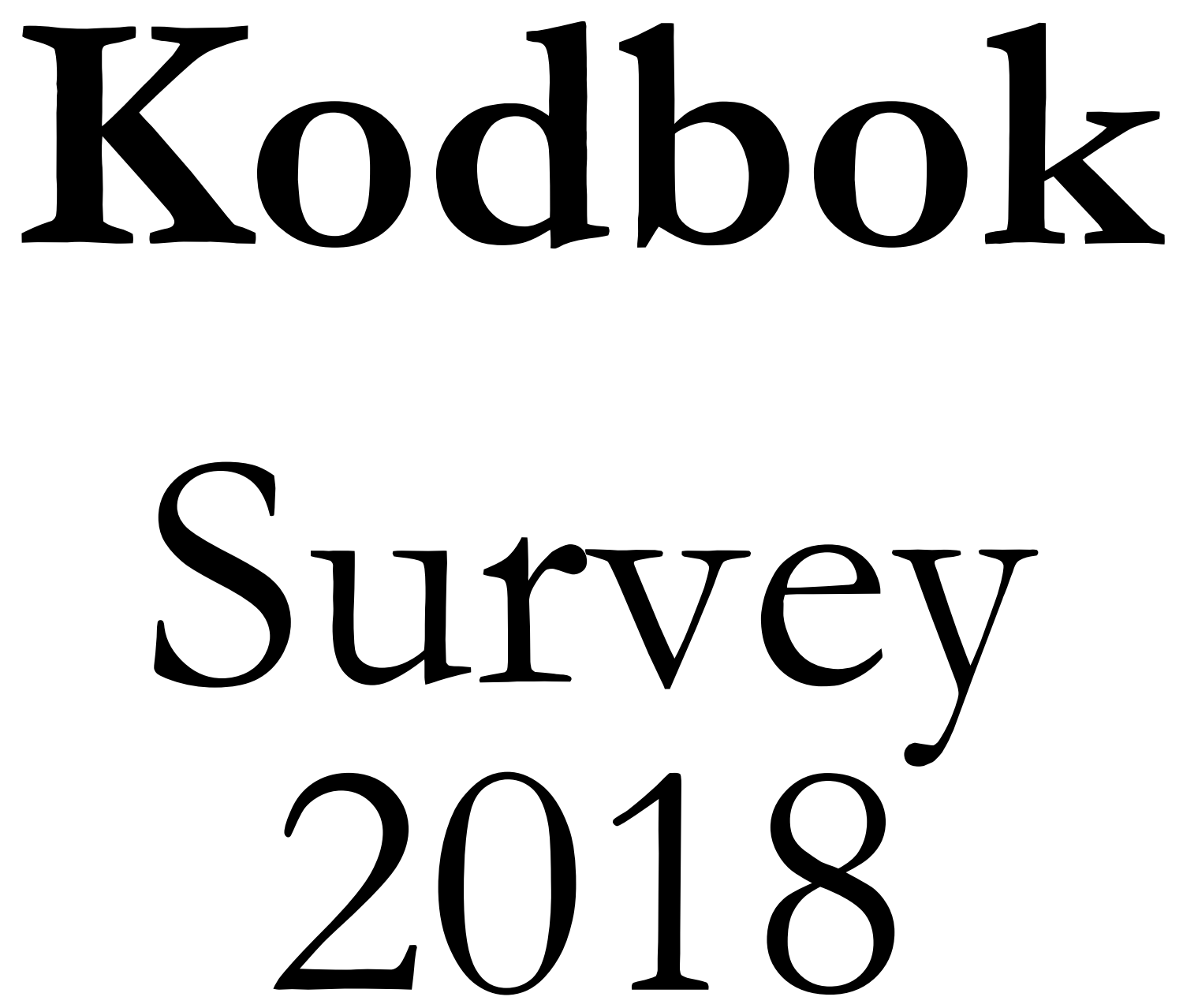

En frågeundersökning om befolkningen i Sverige

\section{- SURVEYINSTITUTET•}

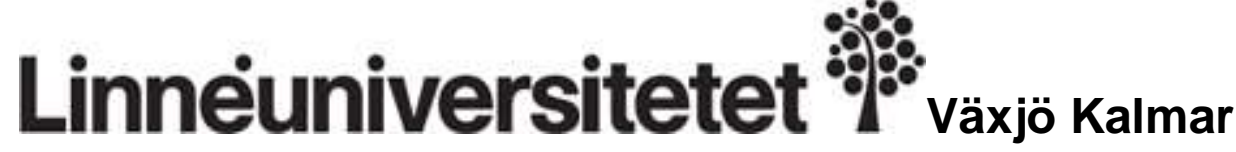




\section{Registervariabler.}

\section{a. INTR}

Intervjunummer: 3-2997

b. Kön

Registerdata, kompletterat med enkätsvar: $0=$ kvinna, $1=$ man.

\section{c. LKF-kod}

LKF-kod, registerdata: 011400-258401 (län=första två siffror, kommun=nästkommande två siffror, församling $=$ sista två siffror).

Länskod:

1 Stockholms län

3 Uppsala län

4 Södermanlands län

5 Östergötlands län

6 Jönköpings län

7 Kronobergs län

8 Kalmar län

9 Gotlands län

10 Blekinge län

11 Skåne län

12 Hallands län

14 Västra Götalands län

17 Värmlands län

18 Örebro län

19 Västmanlands län

20 Dalarnas län

21 Gävleborgs län

22 Västernorrlands län

23 Jämtlands län

24 Västerbottens län

25 Norrbottens län

Kommunkod:

\begin{tabular}{|c|c|c|c|c|c|}
\hline 01 & Stockholms län & 12 & Skåne län & 18 & Örebro län \\
\hline 0114 & Upplands Väsby & 1214 & Svalöv & 1814 & Lekeberg \\
\hline 0115 & Vallentuna & 1230 & Staffanstorp & 1860 & Laxå \\
\hline 0117 & Österåker & 1231 & Burlöv & 1861 & Hallsberg \\
\hline 0120 & Värmdö & 1233 & Vellinge & 1862 & Degerfors \\
\hline 0123 & Järfälla & 1256 & Östra Göinge & 1863 & Hällefors \\
\hline 0125 & Ekerö & 1257 & Örkelljunga & 1864 & Ljusnarsberg \\
\hline 0126 & Huddinge & 1260 & Bjuv & 1880 & Örebro \\
\hline 0127 & Botkyrka & 1261 & Kävlinge & 1881 & Kumla \\
\hline 0128 & Salem & 1262 & Lomma & 1882 & Askersund \\
\hline 0136 & Haninge & 1263 & Svedala & 1883 & Karlskoga \\
\hline 0138 & Tyresö & 1264 & Skurup & 1884 & Nora \\
\hline 0139 & Upplands-Bro & 1265 & Sjöbo & 1885 & Lindesberg \\
\hline 0140 & Nykvarn & 1266 & Hörby & 19 & Västmanlands län \\
\hline 0160 & Täby & 1267 & Höör & 1904 & Skinnskatteberg \\
\hline 0162 & Danderyd & 1270 & Tomelilla & 1907 & Surahammar \\
\hline 0163 & Sollentuna & 1272 & Bromölla & 1960 & Kungsör \\
\hline 0180 & Stockholm & 1273 & Osby & 1961 & Hallstahammar \\
\hline 0181 & Södertälje & 1275 & Perstorp & 1962 & Norberg \\
\hline 0182 & Nacka & 1276 & Klippan & 1980 & Västerås \\
\hline 0183 & Sundbyberg & 1277 & Åstorp & 1981 & Sala \\
\hline 0184 & Solna & 1278 & Båstad & 1982 & Fagersta \\
\hline 0186 & Lidingö & 1280 & Malmö & 1983 & Köping \\
\hline 0187 & Vaxholm & 1281 & Lund & 1984 & Arboga \\
\hline 0188 & Norrtälje & 1282 & Landskrona & 20 & Dalarnas län \\
\hline 0191 & Sigtuna & 1283 & Helsingborg & 2021 & Vansbro \\
\hline 0192 & Nynäshamn & 1284 & Höganäs & 2023 & Malung-Sälen \\
\hline 03 & Uppsala län & 1285 & Eslöv & 2026 & Gagnef \\
\hline 0305 & Håbo & 1286 & Ystad & 2029 & Leksand \\
\hline 0319 & Älvkarleby & 1287 & Trelleborg & 2031 & Rättvik \\
\hline
\end{tabular}




\begin{tabular}{|c|c|c|c|c|c|}
\hline 0330 & Knivsta & 1290 & Kristianstad & 2034 & Orsa \\
\hline 0331 & Heby & 1291 & Simrishamn & 2039 & Älvdalen \\
\hline 0360 & Tierp & 1292 & Ängelholm & 2061 & Smedjebacken \\
\hline 0380 & Uppsala & 1293 & Hässleholm & 2062 & Mora \\
\hline 0381 & Enköping & 13 & Hallands län & 2080 & Falun \\
\hline 0382 & Östhammar & 1315 & Hylte & 2081 & Borlänge \\
\hline 04 & Södermanlands län & 1380 & Halmstad & 2082 & Säter \\
\hline 0428 & Vingåker & 1381 & Laholm & 2083 & Hedemora \\
\hline 0461 & Gnesta & 1382 & Falkenberg & 2084 & Avesta \\
\hline 0480 & Nyköping & 1383 & Varberg & 2085 & Ludvika \\
\hline 0481 & Oxelösund & 1384 & Kungsbacka & 21 & Gävleborgs län \\
\hline 0482 & Flen & 14 & Västra Götalands län & 2101 & Ockelbo \\
\hline 0483 & Katrineholm & 1401 & Härryda & 2104 & Hofors \\
\hline 0484 & Eskilstuna & 1402 & Partille & 2121 & Ovanåker \\
\hline 0486 & Strängnäs & 1407 & Öckerö & 2132 & Nordanstig \\
\hline 0488 & Trosa & 1415 & Stenungsund & 2161 & Ljusdal \\
\hline 05 & Östergötlands län & 1419 & Tjörn & 2180 & Gävle \\
\hline 0509 & Ödeshög & 1421 & Orust & 2181 & Sandviken \\
\hline 0512 & Ydre & 1427 & Sotenäs & 2182 & Söderhamn \\
\hline 0513 & Kinda & 1430 & Munkedal & 2183 & Bollnäs \\
\hline 0560 & Boxholm & 1435 & Tanum & 2184 & Hudiksvall \\
\hline 0561 & Åtvidaberg & 1438 & Dals-Ed & 22 & Västernorrlands län \\
\hline 0562 & Finspång & 1439 & Färgelanda & 2260 & Ånge \\
\hline 0563 & Valdemarsvik & 1440 & Ale & 2262 & Timrå \\
\hline 0580 & Linköping & 1441 & Lerum & 2280 & Härnösand \\
\hline 0581 & Norrköping & 1442 & Vårgårda & 2281 & Sundsvall \\
\hline 0582 & Söderköping & 1443 & Bollebygd & 2282 & Kramfors \\
\hline 0583 & Motala & 1444 & Grästorp & 2283 & Sollefteå \\
\hline 0584 & Vadstena & 1445 & Essunga & 2284 & Örnsköldsvik \\
\hline 0586 & Mjölby & 1446 & Karlsborg & 23 & Jämtlands län \\
\hline 06 & Jönköpings län & 1447 & Gullspång & 2303 & Ragunda \\
\hline 0604 & Aneby & 1452 & Tranemo & 2305 & Bräcke \\
\hline 0617 & Gnosjö & 1460 & Bengtsfors & 2309 & Krokom \\
\hline 0642 & Mullsjö & 1461 & Mellerud & 2313 & Strömsund \\
\hline 0643 & Habo & 1462 & Lilla Edet & 2321 & Åre \\
\hline 0662 & Gislaved & 1463 & Mark & 2326 & Berg \\
\hline 0665 & Vaggeryd & 1465 & Svenljunga & 2361 & Härjedalen \\
\hline 0680 & Jönköping & 1466 & Herrljunga & 2380 & Östersund \\
\hline 0682 & Nässjö & 1470 & Vara & 24 & Västerbottens län \\
\hline 0683 & Värnamo & 1471 & Götene & 2401 & Nordmaling \\
\hline 0684 & Sävsjö & 1472 & Tibro & 2403 & Bjurholm \\
\hline 0685 & Vetlanda & 1473 & Töreboda & 2404 & Vindeln \\
\hline 0686 & Eksjö & 1480 & Göteborg & 2409 & Robertsfors \\
\hline 0687 & Tranås & 1481 & Mölndal & 2417 & Norsjö \\
\hline 07 & Kronobergs län & 1482 & Kungälv & 2418 & Malå \\
\hline 0760 & Uppvidinge & 1484 & Lysekil & 2421 & Storuman \\
\hline 0761 & Lessebo & 1485 & Uddevalla & 2422 & Sorsele \\
\hline 0763 & Tingsryd & 1486 & Strömstad & 2425 & Dorotea \\
\hline 0764 & Alvesta & 1487 & Vänersborg & 2460 & Vännäs \\
\hline 0765 & Älmhult & 1488 & Trollhättan & 2462 & Vilhelmina \\
\hline 0767 & Markaryd & 1489 & Alingsås & 2463 & Åsele \\
\hline 0780 & Växjö & 1490 & Borås & 2480 & Umeå \\
\hline 0781 & Ljungby & 1491 & Ulricehamn & 2481 & Lycksele \\
\hline 08 & Kalmar län & 1492 & Åmål & 2482 & Skellefteå \\
\hline
\end{tabular}




\begin{tabular}{llllll}
0821 & Högsby & 1493 & Mariestad & 25 & Norrbottens län \\
0834 & Torsås & 1494 & Lidköping & 2505 & Arvidsjaur \\
0840 & Mörbylånga & 1495 & Skara & 2506 & Arjeplog \\
0860 & Hultsfred & 1496 & Skövde & 2510 & Jokkmokk \\
0861 & Mönsterås & 1497 & Hjo & 2513 & Överkalix \\
0862 & Emmaboda & 1498 & Tidaholm & 2514 & Kalix \\
0880 & Kalmar & 1499 & Falköping & 2518 & Övertorneå \\
0881 & Nybro & 17 & Värmlands län & 2521 & Pajala \\
0882 & Oskarshamn & 1715 & Kil & 2523 & Gällivare \\
0883 & Västervik & 1730 & Eda & 2560 & Älvsbyn \\
0884 & Vimmerby & 1737 & Torsby & 2580 & Luleå \\
0885 & Borgholm & 1760 & Storfors & 2581 & Piteå \\
09 & Gotlands län & 1761 & Hammarö & 2582 & Boden \\
0980 & Gotland & 1762 & Munkfors & 2583 & Haparanda \\
10 & Blekinge län & 1763 & Forshaga & 2584 & Kiruna \\
1060 & Olofström & 1764 & Grums & & \\
1080 & Karlskrona & 1765 & Årjäng & & \\
1081 & Ronneby & 1766 & Sunne & & \\
1082 & Karlshamn & 1780 & Karlstad & & \\
1083 & Sölvesborg & 1781 & Kristinehamn & & \\
& & 1782 & Filipstad & & \\
& & 1783 & Hagfors & & \\
& & 1784 & Arvika & & \\
\hline
\end{tabular}

\section{Vi börjar med att fråga om dina allmänna värderingar.}

1. Enligt din mening, $i$ vilken utsträckning går det att lita på människor i allmänhet? Kryssa i den ruta som ligger närmast din placering.
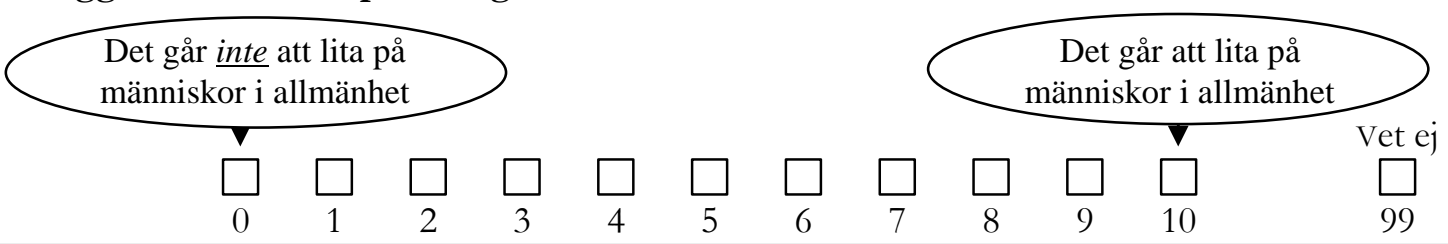

2. Tycker du att människor mest tänker på sig själva eller bryr de sig mycket om andra och sådant vi har gemensamt? Kryssa i den ruta som ligger närmast din placering.
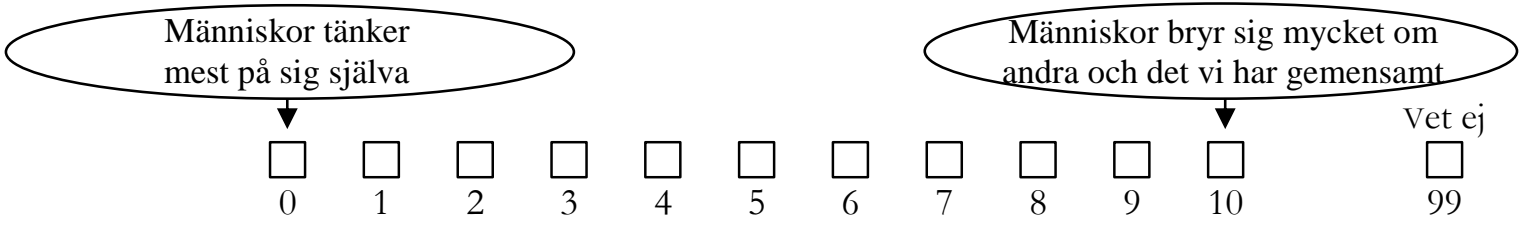

3. Vissa tycker det är bäst med nationell suveränitet där gränser mellan länder har stor betydelse medan vissa tycker att det är bra med globalisering där gränser mellan länder betyder allt mindre. Var någonstans skulle du placera dig på skalan nationell suveränitet - globalisering?

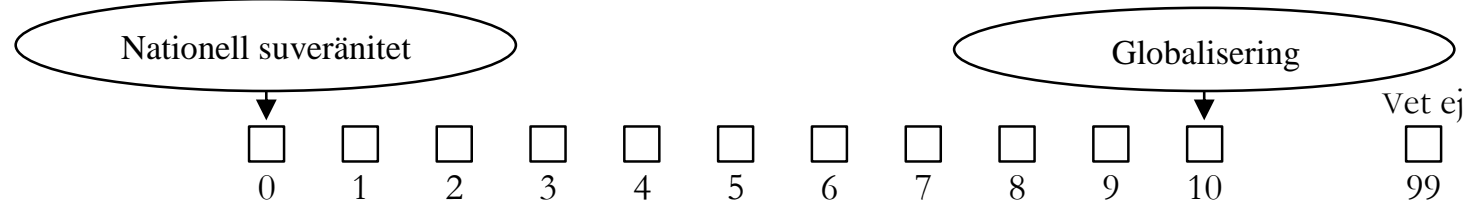

4. I ett samhälle finns olika informella normer om hur folk ska vara. Vissa tycker att de som avviker från majoritetens normer ska anpassa sig till dessa, medan vissa tycker att de som avviker från majoriteten ska få göra det. Var någonstans skulle du placera dig på skalan anpassa sig - få avvika?

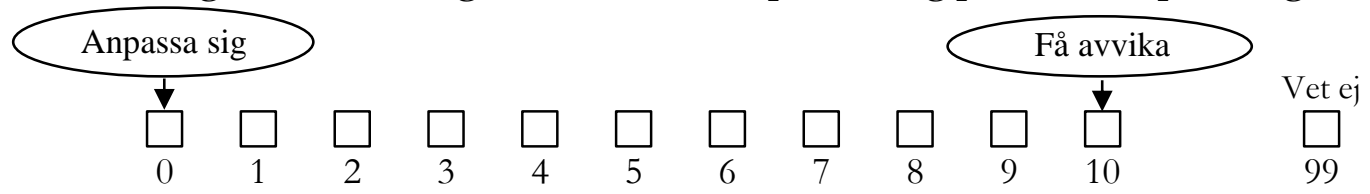


5. Vissa vill att det svenska samhället ska ha en gemensam kultur medan vissa vill att det svenska samhället ska vara mångkulturellt. Var någonstans skulle du placera dig på skalan en gemensam kultur - mångkultur?

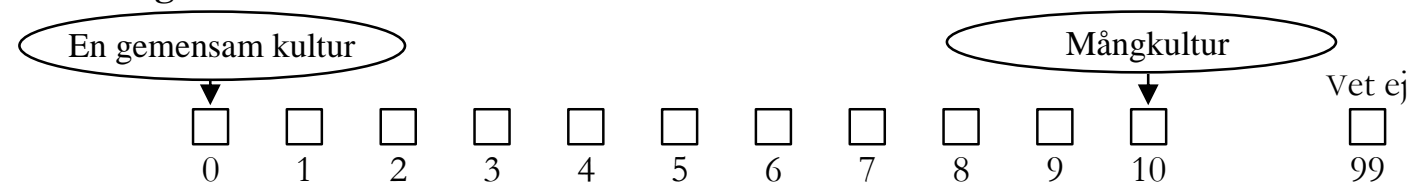

6. Vissa vill att brottslingar ska vårdas medan vissa vill att de ska straffas. Var någonstans skulle du placera dig på skalan vård av kriminella - straff för kriminella?

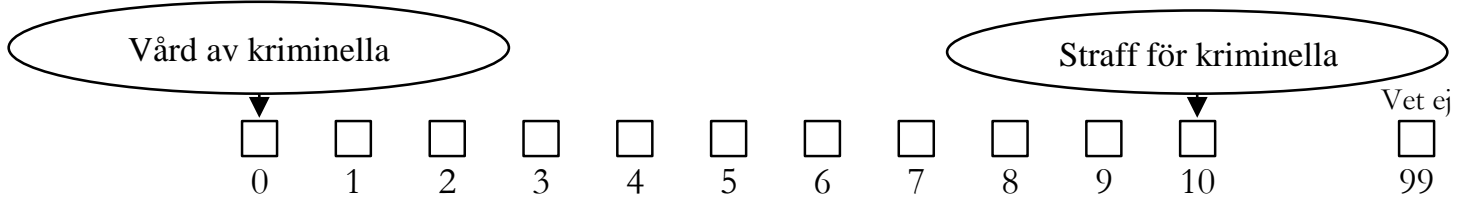

7. När någon blir rik tycker vissa att det oftast beror på individens förutsättningar och personliga val, medan vissa tycker att det oftast beror på andra omständigheter än de som berör individen. Var skulle du placera dig på skalan mellan påståendena att ekonomisk framgång tenderar att bero på individen och ekonomisk framgång tenderar att inte bero på individen?
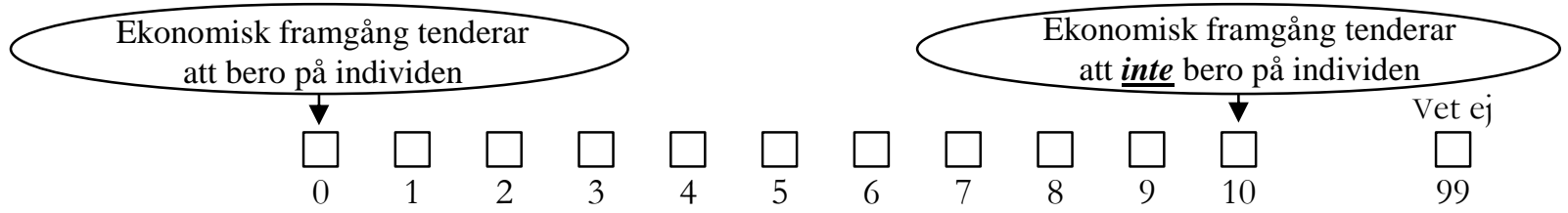

8. Vissa tycker att staten ska ha så stor roll som möjligt i samhällets ekonomi, vissa tycker att statens roll i samhällets ekonomi ska vara så liten som möjligt. Var någonstans skulle du placera dig på skalan stor roll för staten - liten roll för staten?

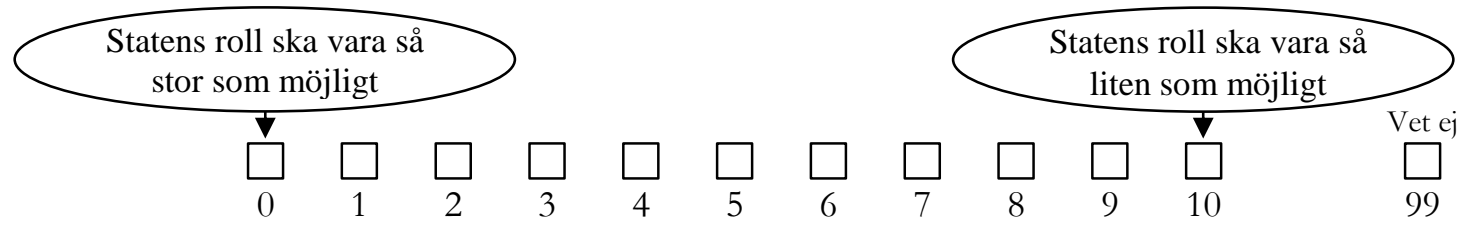

9. Vissa tycker att ekonomisk jämlikhet är viktigt, vissa tycker att ekonomisk jämlikhet är oviktigt. Var någonstans skulle du placera dig på skalan ekonomisk jämlikhet är viktigt - ekonomisk jämlikhet är oviktigt?

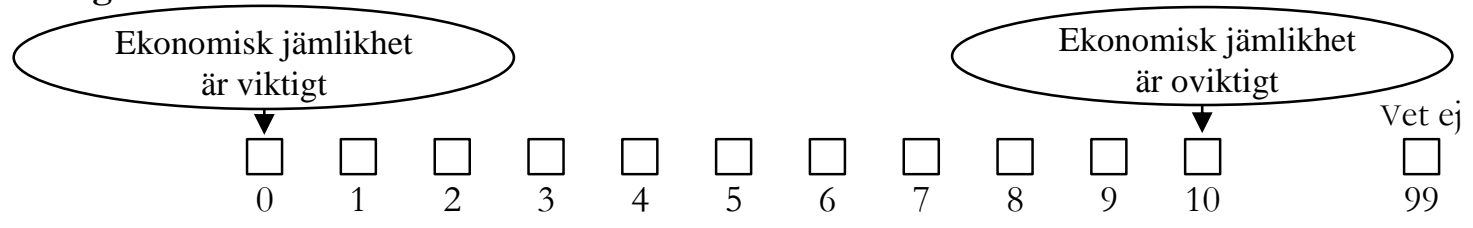

\section{I detta avsnitt frågar vi vad du gjorde i samband med valrörelsen $i$ år.}

10. Hur ofta gjorde du något av följande under valrörelsen i augusti och september?

\footnotetext{
a Diskuterade eller pratade om politik

Kontaktade politiker

c Besökte valmöte

d Fick hembesök vi dörren av politiker

e Läste om politik i tidningen

f Tittade på TV-program om politik

g Tittade på TV-reklam om politik

hyssnade på radioprogram om politik

Lyssnade på radioreklam om politik

Tittade på reklamfilm om politik på internet

k Sökte eller läste om politik på internet

Kommenterade politik på internet
}

$\begin{array}{cccccc}\begin{array}{c}\text { Ingen } \\ \text { gång }\end{array} & \begin{array}{c}\text { Någon } \\ \text { gång }\end{array} & \begin{array}{c}\text { Ett par } \\ \text { gånger }\end{array} & \begin{array}{c}\text { Någon } \\ \text { gång i } \\ \text { veckan }\end{array} & \begin{array}{c}\text { Flera } \\ \text { gånger i } \\ \text { veckan }\end{array} & \begin{array}{c}\text { Varje } \\ \text { dag }\end{array} \\ \square & \square & \square & \square & \square & \square \\ \square & \square & \square & \square & \square & \square \\ \square & \square & \square & \square & \square & \square \\ \square & \square & \square & \square & \square & \square \\ \square & \square & \square & \square & \square & \square \\ \square & \square & \square & \square & \square & \square \\ \square & \square & \square & \square & \square & \square \\ \square & \square & \square & \square & \square & \square \\ \square & \square & \square & \square & \square & \square \\ \square & \square & \square & \square & \square & \square \\ \square & \square & \square & \square & \square & \square \\ 0 & 1 & 2 & 3 & 4 & 5\end{array}$


11. I en valrörelse försöker partierna ge information genom olika kanaler. Från vilka partier har du tagit del av information från nedanstående kanaler? Du kan kryssa i flera rutor.

Kod för markerat svar: 1

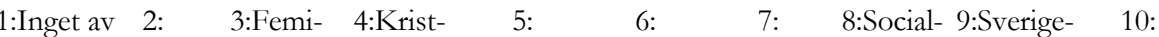

dessa Center- nistiskt demo- Liberal- Miljö- Mode- demo- demo- Vänster-

a Sett partiets TV-reklam

b Sett partiets reklamfilm på internet

c Varit inne på partiets hemsida

d Läst broschyr från partiet

partier partiet initiativ kraterna erna partiet raterna kraterna kraterna partiet

12. Hur intresserad är du i allmänhet av politik?

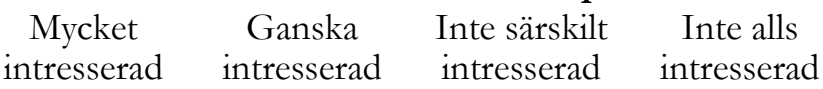

$\begin{array}{llll}\square & \square & \square & \square\end{array}$

\section{Här följer några frågor som handlar om valet och politiska partier.}

13. Nedan nämns några sakområden inom politiken. Kryssa för högst tre sakområden som var viktigast för hur du röstade i riksdagsvalet? Kryssa för högst tre sakområden som nämns nedan.
$\square$ 1:Arbetslöshet/sysselsättning
6:Samhällsekonomi
$\square$ 11:Skola/utbildning $\square$
16:Lag och ordning
$\square$ 2:Ekonomiska skillnader
7:Sjukvård
$\square$ 12:Äldrevård
$\square$ 17:Skatter
3:Internationella frågor
8:Familjepolitik
$\square$ 13:Pensioner
$\square$ 18:Försvar
4:Invandring/flyktingar
9:Landsbygdsfrågor
$\square$ 14:Demokrati
10:Jämställdhet
$\square$ 15:Miljö
$\square \quad$ 19:Energi
$\square \quad$ 20:Bostäder
21:Inget sakområde var speciellt viktigt för hur jag röstade $\square$ 22:Jag röstade inte i riksdagsvalet

14a. Man talar ibland om att politiska åsikter kan placeras in på en vänster-högerskala. Var skulle du placera in dig själv på en sådan vänster-högerskala? Kryssa i den ruta som ligger närmast din placering.

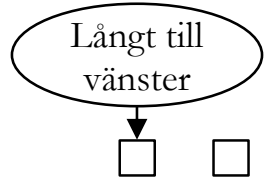

$\begin{array}{ll}\square & \square\end{array}$

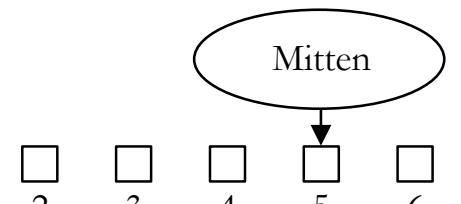

\begin{tabular}{l}
$\square$ \\
\hline
\end{tabular}

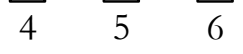

$4 \quad 5 \quad 6$

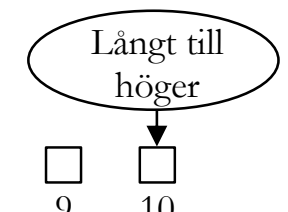

10

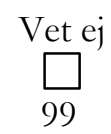

14b. Oavsett var du placerade dig på vänster-högerskalan, anser du dig vara en övertygad anhängare av denna position?
$\square$ Ja, mycket övertygad
$\square$ Ja, något övertygad
$\square \mathrm{Nej}$

15. Var någonstans skulle du placera in respektive politiskt parti på vänster-högerskalan? Kryssa i den ruta som ligger närmast din uppfattning om partiets placering.
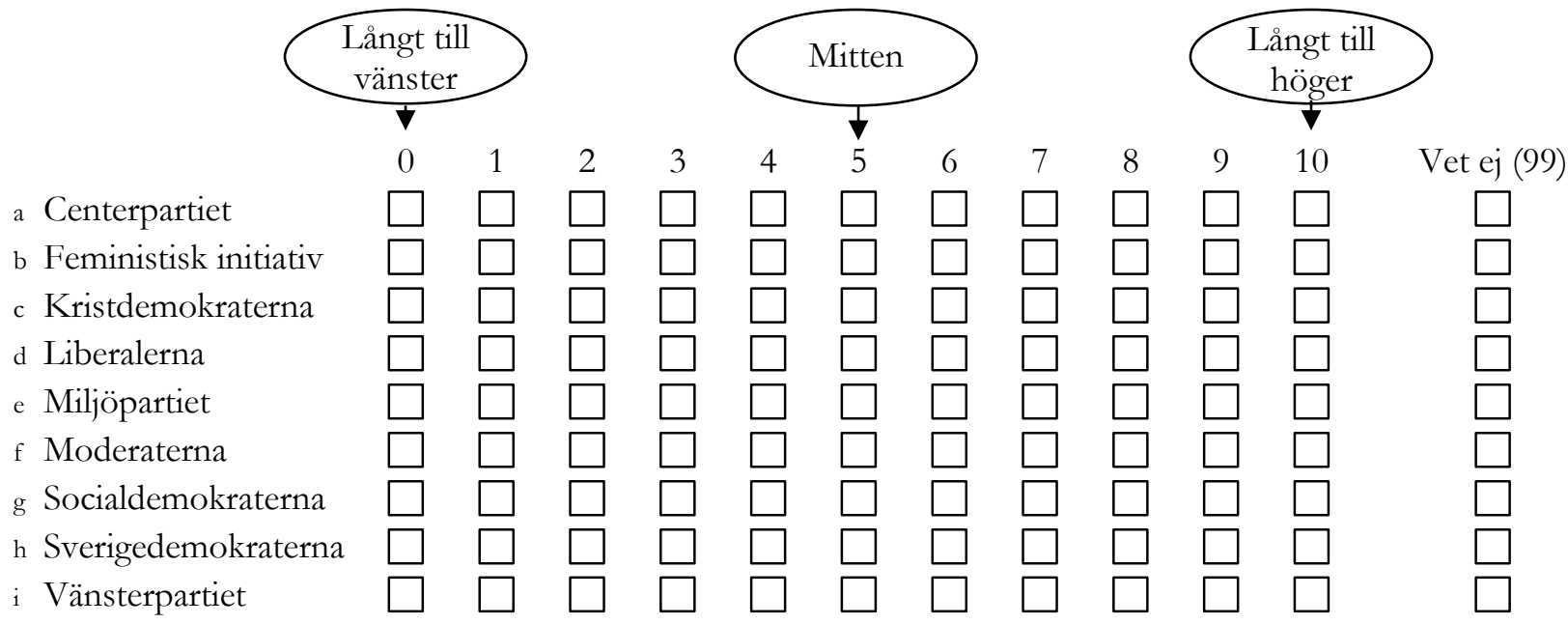

16. Är du medlem i ett politiskt parti eller dess ungdoms- eller kvinnoförbund?

$\square_{1} \mathrm{Ja} \quad \square_{2} \mathrm{Nej}$


17. I vilken utsträckning anser du att de politiska partierna i riksdagen väsentligen skiljer sig åt då det gäller politiska sakfrågor?

$\begin{array}{cccc}\begin{array}{c}\text { I mycket stor } \\ \text { utsträckning }\end{array} & \begin{array}{c}\text { I ganska stor } \\ \text { utsträckning }\end{array} & \begin{array}{c}\text { I ganska liten } \\ \text { utsträckning }\end{array} & \text { Inte alls } \\ \square & \square & \square_{3} & \square\end{array}$

\section{8a.Vilket parti tycker du bäst om idag?}

$\begin{array}{lll}1 & \square & \text { Centerpartiet } \\ 2 & \square & \text { Feministiskt initiativ } \\ 3 & \square & \text { Kristdemokraterna } \\ 4 & \square & \text { Liberalerna } \\ 5 & \square & \text { Miljöpartiet }\end{array}$

$6 \square$ Moderaterna

$7 \square$ Socialdemokraterna

$8 \square$ Sverigedemokraterna

$9 \square$ Vänsterpartiet

$10 \square$ Annat parti (v.g. ange vilket):

18b. Anser du dig vara en övertygad anhängare av detta parti?
$\square$ Ja, mycket övertygad
$\square$ Ja, något övertygad
$\square \mathrm{Nej}$

19. Vilka partier skulle du kunna tänka dig att rösta på i ett riksdagsval? Du kan kryssa för flera svar.
a $\square$ Centerpartiet
f $\square$ Moderaterna
b $\square$ Feministiskt initiativ
g $\square$ Socialdemokraterna
c $\square$ Kristdemokraterna
h $\square$ Sverigedemokraterna
d $\square$ Liberalerna
e $\square$ Miljöpartiet
i $\square$ Vänsterpartiet
j $\square$ Annat parti (v.g. ange vilket):

Kod för markerat svar: 1

20. I politiken talas det ibland om Alliansen (Moderaterna, Centerpartiet, Liberalerna och Kristdemokraterna) samt De rödgröna (Socialdemokraterna, Vänsterpartiet och Miljöpartiet). Vilket av dessa två politiska block tycker du bäst om idag?
$1 \square$ Alliansen
$2 \square$ De rödgröna
3
Inget av blocken

Anser du dig vara en övertygad anhängare till detta politiska block?

$1 \square \mathrm{Ja}$, mycket övertygad $\quad 2 \square \mathrm{Ja}$, något övertygad $3 \square \mathrm{Nej}$

21. Var någonstans skulle du placera in de politiska blocken på vänster-högerskalan? Kryssa i den ruta som ligger närmast din uppfattning om partiets placering.
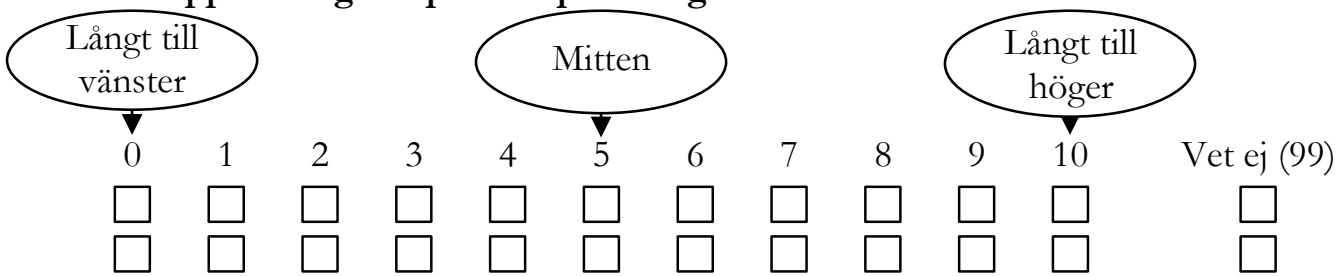

a Alliansen

b De rödgröna
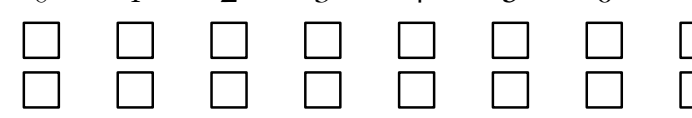

22. I vilken utsträckning anser du att Alliansen och De rödgröna väsentligen skiljer sig åt då det gäller politiska sakfrågor?

$\begin{array}{cccc}\begin{array}{c}\text { I mycket stor } \\ \text { utsträckning }\end{array} & \begin{array}{c}\text { I ganska stor } \\ \text { utsträckning }\end{array} & \begin{array}{c}\text { I ganska liten } \\ \text { utsträckning }\end{array} & \text { Inte alls } \\ \square & \square & \square\end{array}$

23. Vilket parti röstade du på i riksdagsvalet 2018?

$11 \square$ Jag röstade inte (om du inte röstat, gå vidare till fråga 29)

$1 \square$ Centerpartiet $6 \square$ Moderaterna

$2 \square$ Feministiskt initiativ $7 \square$ Socialdemokraterna

$3 \square$ Kristdemokraterna $8 \square$ Sverigedemokraterna

$4 \square$ Liberalerna

$9 \square$ Vänsterpartiet

$5 \square$ Miljöpartiet

$10 \square$ Annat parti (v.g. ange vilket):

24. När bestämde du dig för vilket parti du skulle rösta på i riksdagsvalet 2018?

$\begin{array}{ccccc}\begin{array}{c}\text { Långt } \\ \text { före valet }\end{array} & \begin{array}{c}\text { Någon månad } \\ \text { före valet }\end{array} & \begin{array}{c}\text { Några veckor } \\ \text { före valet }\end{array} & \begin{array}{c}\text { Veckan } \\ \text { före valet }\end{array} & \begin{array}{c}\text { Under } \\ \text { valdagen }\end{array} \\ \square & \square & \square & \square & \square \\ 1 & 2 & 3 & \square & 5\end{array}$


25. När det gäller partiet du röstade på i riksdagsvalet, gillade du partiet eller partiledaren (språkrören) mest? Svara med hjälp av nedanstående skala. Kryssa i den ruta som ligger närmast din placering.

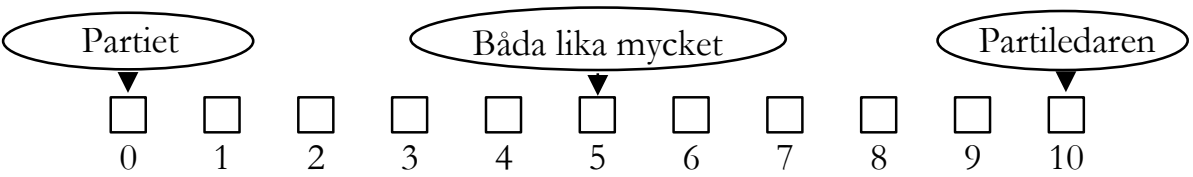

26. Riksdagens 4-procentspärr kan ha betydelse för hur väljare röstar. Vilket av följande påståenden passar bäst in på hur de tänkte när du röstade?

$1 \square$ Jag röstade på det parti jag tyckte var bäst och jag var säker på att det skulle komma över 4-procentspärren

$2 \square$ Jag röstade på det parti jag tyckte var bäst, även om jag var osäker på att de skulle komma över 4-procentspärren

$3 \square$ Jag röstade på ett annat parti som låg nära 4-procentsspärren istället för det parti jag tyckte var bäst

$4 \square$ Istället för att rösta på det parti jag tyckte var bäst, röstade jag på ett annat parti som jag trodde hade större möjligheter att komma över 4-procentspärren

27. Röstade du på ett parti i ett politiskt block fast du egentligen tyckte bättre om ett parti som inte var med i detta politiska block?

$1 \square$ Jag röstade på det parti jag tyckte var bäst

$2 \square$ Jag röstade på ett av de rödgröna partierna, fast jag tyckte ett parti i den borgerliga alliansen var bättre

$3 \square$ Jag röstade på ett av alliansens partier, fast jag tyckte att ett parti bland de rödgröna var bättre

28. När du röstar har du möjlighet att rösta på en person genom att sätta ett kryss framför ett namn på valsedeln. Använde du denna möjlighet när du röstade i riksdagsvalet?

$1 \square$ Ja, jag kryssade för första namnet som var överst på valsedeln

$2 \square \mathrm{Ja}$, jag kryssade för något av namnen som stod tvåa eller trea på valsedeln

$3 \square \mathrm{Ja}$, jag kryssade för ett namn som stod längre ned på valsedeln

$4 \square \mathrm{Nej}$

29. Vilket parti röstade du på i förra riksdagsvalet 2014?

$11 \square$ Jag röstade inte

$12 \square$ Jag vet inte vilket parti jag röstade på

$1 \square$ Centerpartiet

$2 \square$ Feministiskt initiativ

$3 \square$ Kristdemokraterna

$4 \square$ Liberalerna (dåvarande Folkpartiet)

$5 \square$ Miljöpartiet

$6 \square$ Moderaterna

$7 \square$ Socialdemokraterna

$8 \square$ Sverigedemokraterna

$9 \square$ Vänsterpartiet

$10 \square$ Annat parti (v.g. ange vilket): .......................

30. Vilka partier skulle du vilja ingick regeringen efter riksdagsvalet 2018?
a $\square$ Centerpartiet
f $\square$ Moderaterna
b $\square$ Feministiskt initiativ
g $\square$ Socialdemokraterna
Kristdemokraterna
h $\square$ Sverigedemokraterna
d $\square$ Liberalerna
i $\square$ Vänsterpartiet
e $\square$ Miljöpartiet
j $\square$ Annat parti (v.g. ange vilket):

Kod för markerat svar: 1

31. Om du tänker på det demokratiska systemet i vårt land, hur väl anser du att det fungerar?
Mycket bra
Ganska bra
$\square$

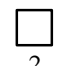
Ganska dåligt
Mycket dåligt

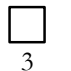
$\square$

32. Om du tänker på det senaste riksdagsvalet, tror du att det genomfördes på ett korrekt sätt eller fanns det problem som gjorde att riksdagsvalet inte genomfördes korrekt?

Helt korrekt I stort sett korrekt Delvis inte korrekt Inte alls korrekt

$\begin{array}{llll}\square & \square & \square & \square \\ 1 & \square_{2} & \square\end{array}$

33. Genom vilka kanaler har du fått information om riksdagsvalet sköttes korrekt eller om det fanns problem? Du kan kryssa för flera svar.
a $\square$ I samtal med andra
c $\square$ Papperstidning
b $\square \mathrm{TV} /$ radio
d $\square$ Tidning på nätet
e $\square$ Sajt på nätet
f $\square$ Sociala medier
Kod för markerat svar: 1


Följande frågor handlar om ekonomi och politik.

34. Vilken är din åsikt om följande förslag?

\begin{tabular}{|c|c|c|c|}
\hline $\begin{array}{l}\text { Mycket } \\
\text { bra }\end{array}$ & $\begin{array}{c}\text { Ganska } \\
\text { bra }\end{array}$ & $\begin{array}{c}\text { Varken } \\
\text { bra eller } \\
\text { dåligt }\end{array}$ & $\begin{array}{c}\text { Ganska } \\
\text { dåligt }\end{array}$ \\
\hline
\end{tabular}

a Minska den offentliga sektorn

b Ingen vinstutdelning i skattefinansierad vård, skola och omsorg

c Sänk skatterna

d Höj ersättningen i arbetslöshetsförsäkringen

e Avskaffa RUT-avdraget för hushållsnära tjänster

f Höj ersättningen i sjukförsäkringen

g Satsa på ökad ekonomisk tillväxt även om det

innebär ökade inkomstskillnader

h Höj koldioxidskatten
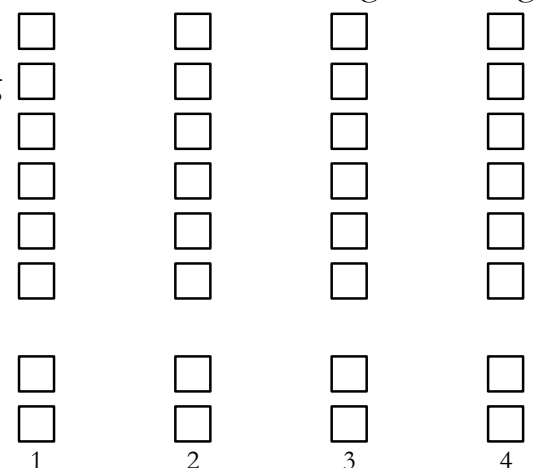

$\square$

35. Om du ser tillbaka ungefär fyra år i tiden, tycker du att svensk ekonomi klarat sig bättre eller sämre jämfört med andra europeiska länder?

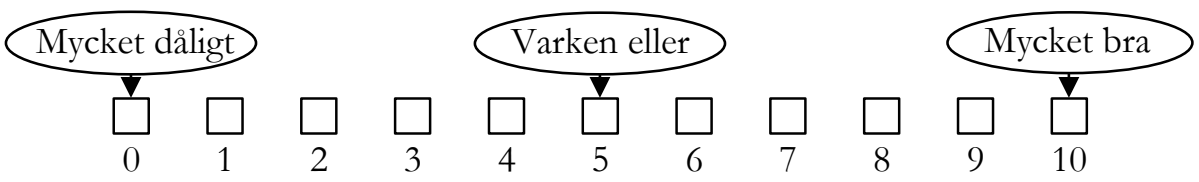

36. Oavsett vilka partier som sitter i den nuvarande regeringen, vilket av de båda politiska blocken tror du skulle vara bäst för svensk ekonomi de kommande fyra åren?

Helt klart den

borgerliga alliansen
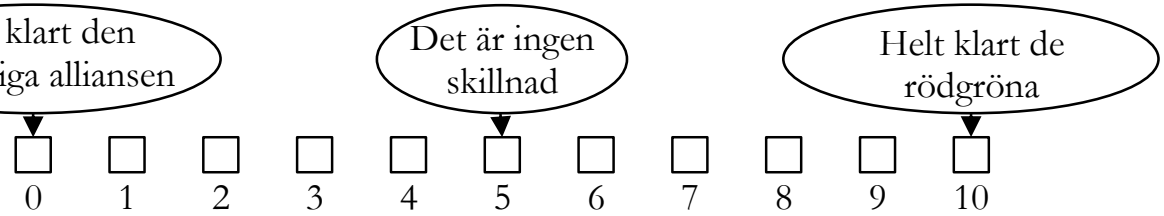

37. Om du ser tillbaka fyra år i tiden och tänker på din egen ekonomi, tycker du att den har förbättras eller försämrats?

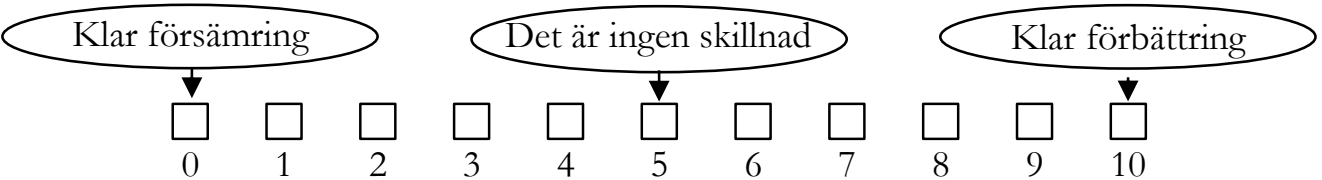

38. Oavsett vilka partier som sitter i den nuvarande regeringen, vilket av de båda politiska blocken tror du skulle vara bäst för din egen ekonomi de kommande fyra åren?
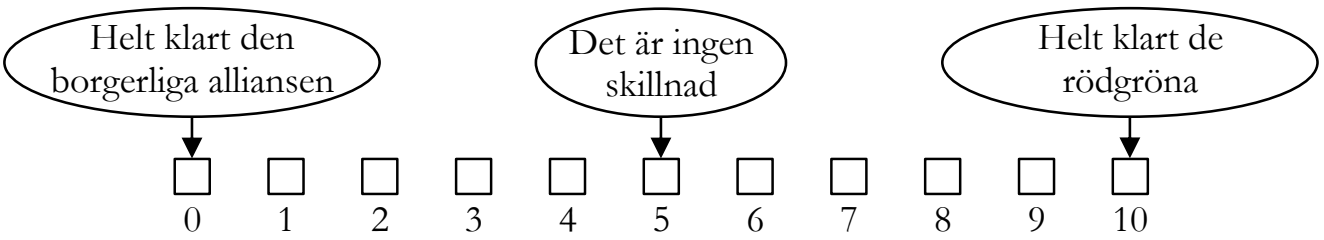

\section{Dessa frågor handlar om vad du tycker om de som bestämmer.}

39. Tycker du att svenska politiker respekterar ditt sätt att leva?
Ja, i mycket stor
Ja, i ganska stor
Nej, i ganska liten
Nej,
utsträckning
utsträckning
utsträckning
inte alls
$\square$
$\square$
$\square$

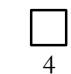

40. I vilken omfattning instämmer du i följande påstående: "De flesta svenska politiker och makthavare tillhör en oärlig, maktfullkomlig och avskild grupp som inte bryr sig om vanligt folks åsikter?” Kryssa i den ruta som ligger närmast din uppfattning.

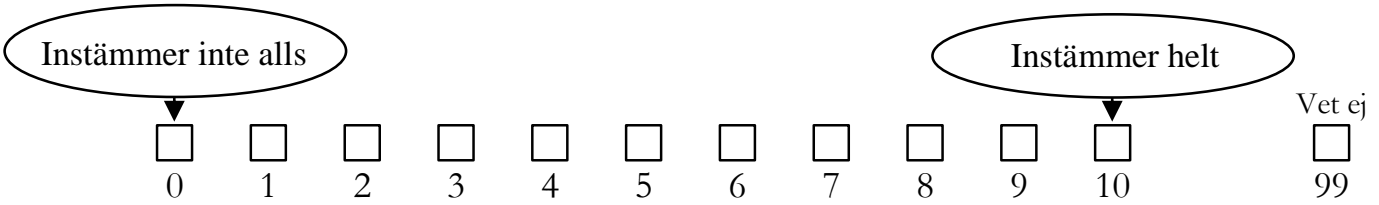

I detta avsnitt handlar frågorna om religion. 
41. Är du något av följande?

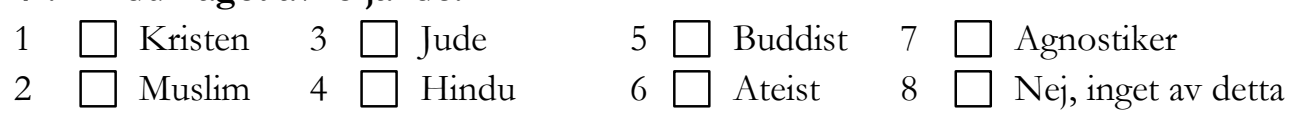

42. Vilket av följande påståenden stämmer bäst överens med din egen ståndpunkt?

$1 \square$ Det finns en Gud.

$2 \square$ Det kanske inte finns en gud, men det finns något, en högre makt eller andevärld.

$3 \square$ Det finns ingen gud, högre makt eller andevärld.

$4 \square$ Vet ej.

43. Hur ofta har du under de senaste 12 månaderna giort följande?

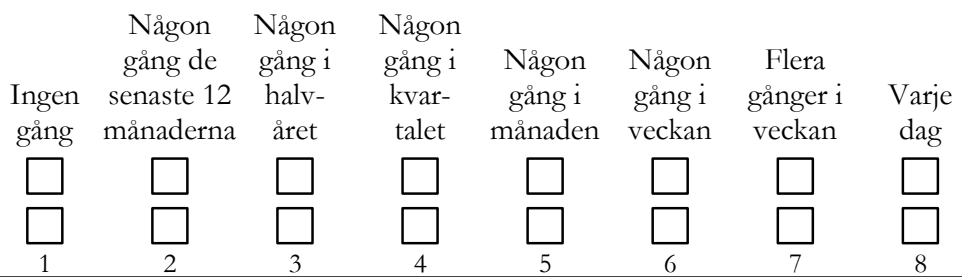

44. Har du haft erfarenhet av att bli frälst, omvänd, född på nytt eller haft någon religiös avgörelsepunkt?

$1 \square \mathrm{Ja} \quad 2 \square$ Nej $\quad 3 \square$ Vet ej

45. Under din uppväxttid då du bodde i ditt föräldrahem, ungefär hur ofta tror du att någon av dina föräldrar besökte en gudstjänst?
Aldrig
Någon gång
Minst någon
gång $\mathrm{i}$ månaden
Vet ej
a Din mor
b Din far
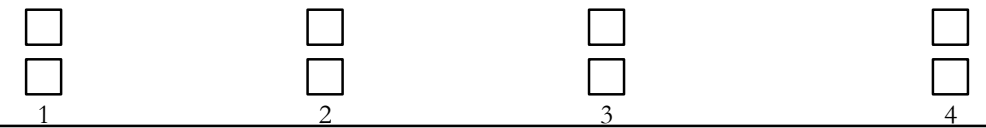

46. Tillhör du någon av följande kyrkor eller religiösa organisationer?

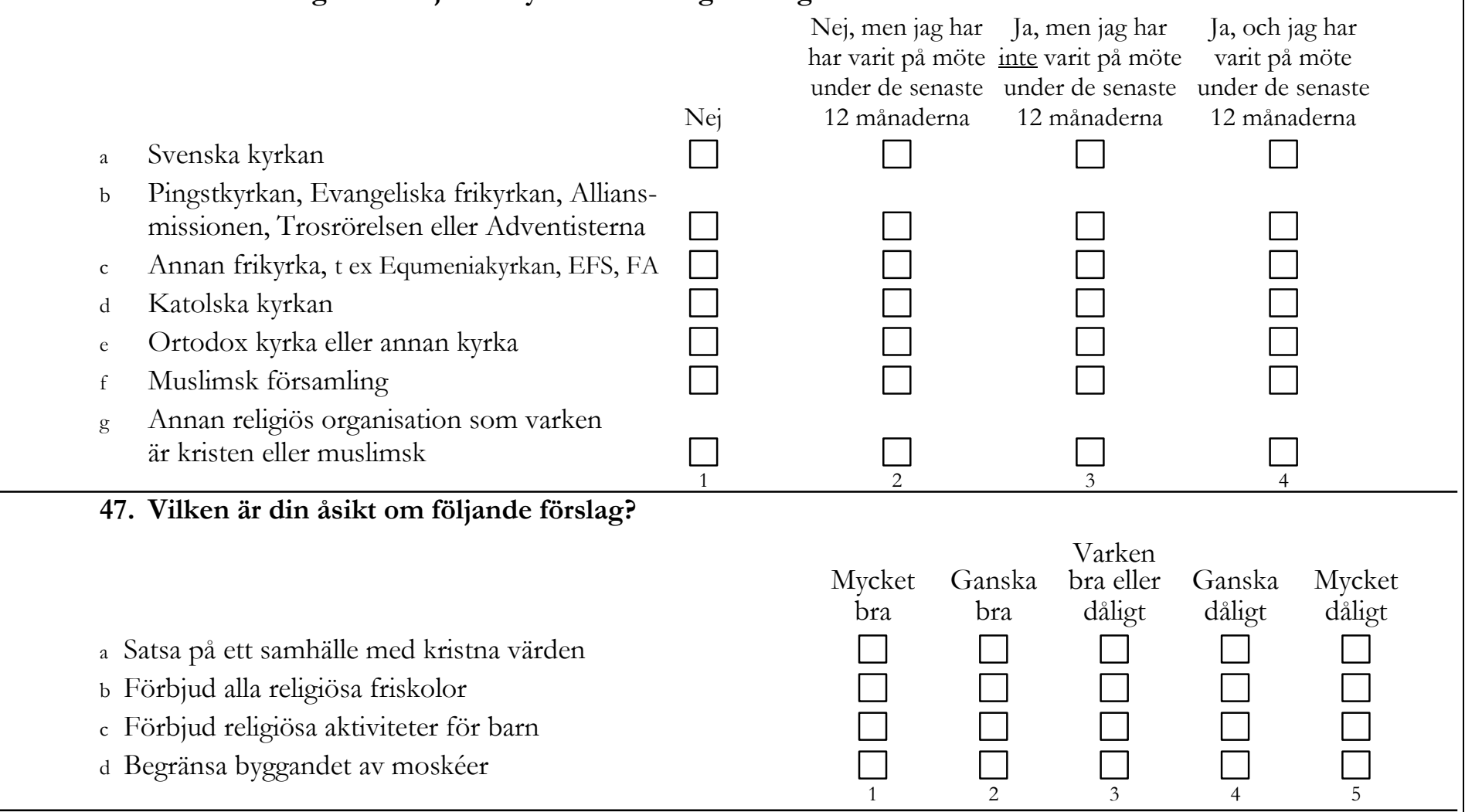

48. I vilken utsträckning ger dig religion positiva eller negativa känslor? Kryssa i den ruta som ligger närmast din uppfattning.

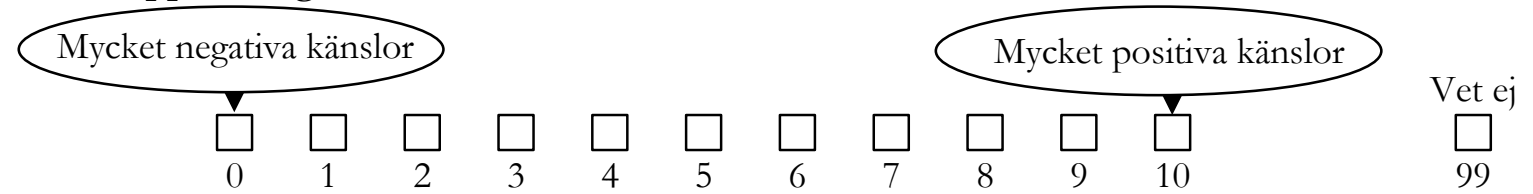


49. Vilken är din inställning till följande påståenden?

a Vetenskap har gjort religion onödigt

b Religion förhindrar människors möjligheter att uttrycka och förverkliga sig

c Det finns ingen anledning att tro på en gud, men däremot på människan

d Religion är dåligt för att det motverkar socialism

e Religion leder till dogmatism och fundamentalism

f Religiositet hör inte till den svenska kulturen

Religion är verklighetsflykt

Religioner leder till våldsamma konflikter

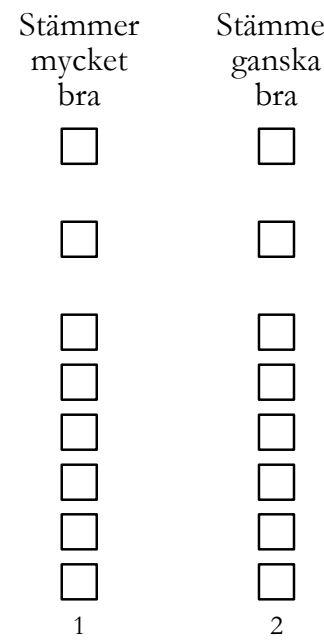
Varken
eller

Stämmer

ganska Stämmer

dåligt inte alls

\section{Här frågar vi om din åsikt i olika politiska sakfrågor.}

50. Vilken är din åsikt om följande förslag?

a Inför hårdare fängelsestraff för brottslingar

b Inför dödsstraff för mord

c Satsa på ett mångkulturellt samhälle

d Sverige bör ta emot färre flyktingar

e Minska möjligheten till fri abort

f Satsa kraftfullt för att öka jämställdheten mellan kvinnor och män

g Lagstifta om att båda föräldrarna måste dela lika på föräldrapenningen

h Läkare ska ha rätt att hjälpa en obotligt och svårt sjuk patient att dö

i Inför betyg från första klass i grundskolan

j Lärare ska få bestämma mer över eleverna

k Satsa på miljön även om det innebär lägre ekonomisk tillväxt

1 Tillåt försäljning av öl, vin och sprit i livsmedelsaffärer

m Stärk försvaret även om det kostar mer pengar

n Sverige bör ansöka om medlemskap i NATO

o Minska den svenska statens bistånd till fattiga länder

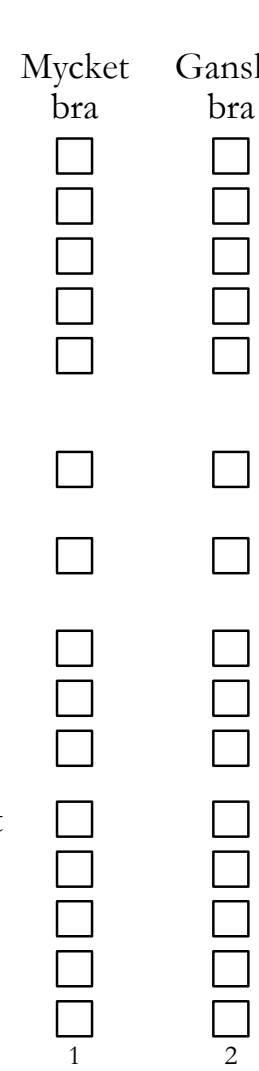

Varken
bra eller

bra eller Ganska Mycket

dåligt

dåligt dåligt
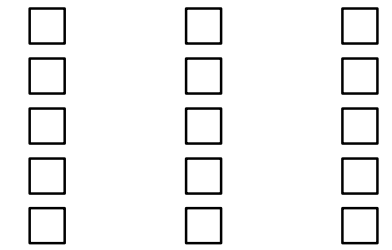

\section{I det sista avsnittet ställs några frågor om din bakgrund och uppväxt.}

51. Är du kvinna eller man?

$1 \square$ Kvinna $2 \square$ Man $3 \square$ Annat, nämligen...

52. Vilket år är du född?

Årtal:

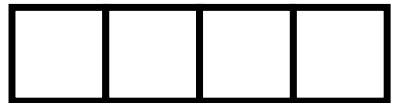

Kod: födelseårtal

53. Vilket år föddes dina föräldrar?

a Din far:

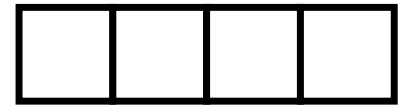

b Din mor:

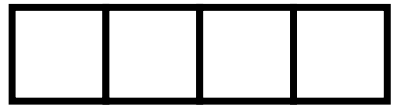

Kod: födelseårtal 
54. Om du skulle beskriva ditt nuvarande hem respektive det hem du växte upp i, vilket av nedanstående alternativ stämmer då bäst?
a Ditt nuvarande hem:
b Det hem du växte upp $i$ :
$1 \square$ Arbetarhem
$1 \square$ Arbetarhem
$2 \square$ Jordbrukarhem
$2 \square$ Jordbrukarhem
$3 \square$ Tjänstemannahem
$3 \square$ Tjünstemannahem
$4 \square$ Högre tjänstemanna-/akademikerhem
$4 \square$ Högre tjänstemanna-/akademikerhem
$5 \square$ Företagarhem
$5 \square$ Företagarhem

55. Hur upplevde du din familjs ekonomi under din uppväxt?
Mycket svag
(a)
1

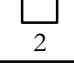
Ganska svag
Varken svag
eller god
$\square$
Ganska god
$\square$
Mycket god
$\square$

56. I vilken typ av område bor du?
$1 \square$ Storstad, centralt
$2 \square$ Storstad, ytterområde/förort
$4 \square$ Stad eller större tätort, ytterområde
$3 \square$ Stad eller större tätort, centralt
$5 \square$ Mindre tätort
$6 \square$ Ren landsbygd

57. Var någonstans har du, respektive din mor och far, huvudsakligen vuxit upp?
Ren landsbygd
a Du själv
$b$ Din mor
c Din far
Mindre tätort
$1 \square$
$1 \square$
$1 \square$
Stad eller större tätort
2
Storstad (t ex Stockholm, Göteborg, Malmö)
$3 \square$
2
2
$3 \square$
4
4
$3 \square$
4

58. I vilket land har du, respektive din mor och far, huvudsakligen vuxit upp?
I Sverige
a Du själv
b Din mor
c Din far
Annat land i Norden
$1 \square$
$1 \square$
$1 \square$
Annat land i Europa
$2 \square$
$2 \square$
$2 \square$
Annat land utanför Europa
$3 \square$
$3 \square$
$3 \square$
$4 \square$
$4 \square$
$4 \square$

59. Är du ...?

Svensk medborgare

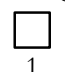

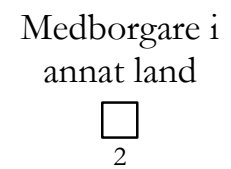

Både svensk medborgare och medborgare $i$ annat land

\section{Vilken skolutbildning har du? Markera det alternativ som du anser passar bäst in på dig.}
$1 \square$ Ej fullgjort grundskola eller motsvarande obligatorisk skola
$2 \square$ Grundskola eller motsvarande obligatorisk skola
$3 \square$ Studier vid gymnasium, folkhögskola eller motsvarande
$4 \square$ Examen från gymnasium, folkhögskola eller motsvarande
$5 \square$ Eftergymnasial utbildning, ej högskola
$6 \square$ Studier vid högskola/universitet
$7 \square$ Examen från högskola/universitet
$8 \square$ Examen från forskarutbildning

61. Vilken inriktning har din utbildning i huvudsak? Kryssa för det svar som bäst stämmer in på din utbildning. Kryssa endast för ett svar.

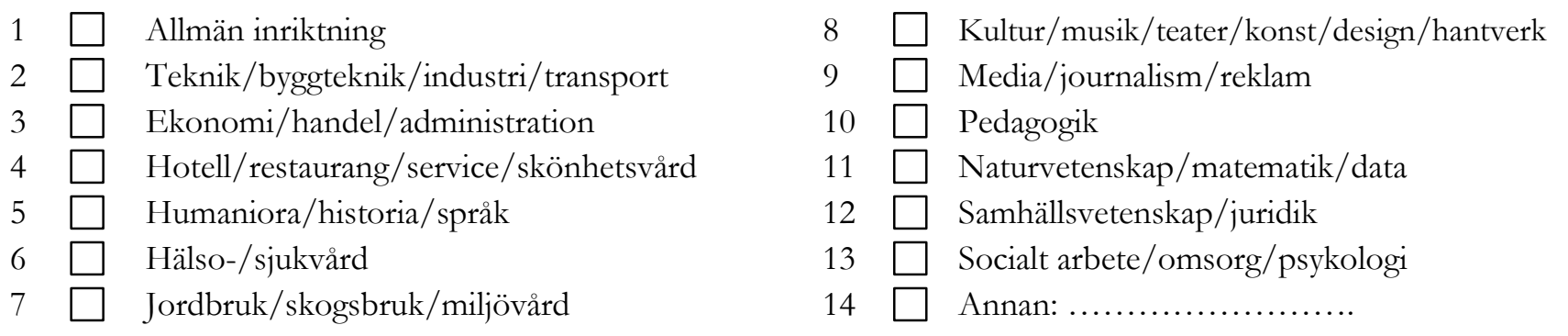


62. Vilken av de här grupperna tillhör du för närvarande? Du kan kryssa för flera svar.

Kod för markerat
a $\square$ Förvärvsarbetande
b $\square$ Föräldraledig
c $\square$ Sjukskriven
d $\square$ Har arbete i arbetsmarknadspolitiska åtgärder
e $\square$ Genomgår arbetsmarknadsutbildning

f $\square$ Arbetslös med a-kassa

svar: 1

g $\square$ Ålderspensionär/avtalspensionär

h $\square$ Förtidspensionär/sjukpensionär

i $\square$ Studerande

j $\square$ Annat:

63. Arbetar eller arbetade du i statlig, kommunal, landstingskommunal eller privat tjänst? Om du är tillfälligt utan arbete eller pensionär kryssar du för det som stämmer med ditt senaste yrke.

$\square$ Statlig $\square$ Kommunal $\square$ Landsting $\square_{4}$ Privat $\square_{5}$ Ideell $\square_{6}$ Inget av dessa

64. Vilken av de här yrkesgrupperna hör eller hörde du till? Om du är tillfälligt utan arbete eller pensionär kryssar du för din senaste yrkesgrupp.
$1 \square$ Tjänsteman
$6 \square$ Företagare: ingen anställd
$2 \square$ Tjänsteman med arbetsledande funktion $\quad 7 \quad \square \quad$ Företagare: 1-9 anställda
$3 \square$ Tjänsteman med företagsledande funktion $8 \square \quad$ Företagare: 10 eller fler anställda
$4 \square$ Arbetare
$9 \square$ Jordbrukare: ingen anställd
$5 \square$ Arbetare med arbetsledande funktion
10
Jordbrukare: en eller flera anställda

$11 \square$ Jag har aldrig tillhört någon av dessa yrkesgrupper

65. Arbetar eller arbetade du hel- eller deltid? Om du är tillfälligt utan arbete eller pensionär kryssar du för din senaste arbetstid.

$1 \square$ Heltid (eller mer)

$2 \square$ Deltid, minst 15 timmar i veckan

$3 \square$ Deltid, mindre än 15 timmar i veckan

$4 \square$ Jag har aldrig yrkesarbetat

66. Var vänlig och sätt ett kryss i den ruta som motsvarar din ungefärliga sammanlagda årsinkomst $i$ kronor före skatt (pension och studiemedel ska räknas in i den ungefärliga årsinkomsten).
$1 \square 100000$ eller mindre
$5 \square 400001-500000$
$2 \square 100001-200000$
$6 \square 500001-600000$
$3 \square 200001-300000$
$7 \square 600001-700000$
$4 \square 300001-400000$
$8 \square$ Merän 700000

67. Var vänlig sätt ett kryss $i$ den ruta som motsvarar den ungefärliga sammanlagda årsinkomsten $i$ kronor för samtliga personer $i$ ditt hushåll före skatt (pension och studiemedel ska räknas in i den ungefärliga årsinkomsten).
$1 \square 100000$ eller mindre
$2 \square 100001-200000$
$5 \square 400001-500000$
$3 \square 200001-300000$
$6 \square 500001-600000$
$\square 300001-400000$
$7 \square 600001-700000$
$8 \square$ Merän 700000

68. Är du medlem i någon fackförening?

Ja, förbund inom:

$1 \square$ LO (Landsorganisationen)

$2 \square$ TCO (Tjänstemännens Centralorganisation)

$3 \square$ SACO (Sveriges Akademikers Centralorganisation)

$4 \square$ Annan facklig organisation

$5 \square \mathrm{Nej}$

69. Vilket är ditt civilstånd?

$\begin{array}{cccc}\text { Ensamstående } & \text { Sambo } & \text { Gift/partnerskap } & \text { Änka/änkling } \\ \square & \square & \square & \square\end{array}$

70. Har du egna barn?

$1 \square \quad \mathrm{Nej}$

$2 \square \quad$ Ja och den yngste är 0-5 år

$3 \square \quad$ Ja och den yngste är 6-12 år

$5 \square$ Ja och den yngste är 19-25 år

$4 \square$ Ja och den yngste är 13-18 år

$6 \quad \square \quad$ Ja och den yngste är 26-35 år

$7 \square \quad \square \quad$ Ja och den yngste är över 35 år 


\section{ETTT STORT TACK FÖR DIN MEDVERKAN!}

Om du har synpunkter på någon enskild fråga eller formuläret som helhet är vi tacksamma för att få ta del av dessa.

\section{- SURVEYINSTITUTET·}

Surveyinstitutet genomför vetenskapliga frågeundersökningar som en del av verksamheten vid Linnéuniversitetet. Surveyinstitutets undersökning utgör ett viktigt bidrag till universitetets forskning om det svenska samhället. Den nationella undersökningen Survey 2018 går till totalt 3000 slumpmässigt utvalda personer boende i Sverige och genomförs i samarbete med Kantar-Sifo. Huvudansvarig för undersökningen är docent Magnus Hagevi, Linnéuniversitetet.

Har du frågor som rör din medverkan i undersökningen, ring gärna Kantar-Sifo, telefon: 020-252526 (samtalet är kostnadsfritt).

Du kan också ringa eller skicka e-post till Magnus Hagevi, Surveyinstitutet vid Linnéuniversitetet, telefon: 0470708022, e-post: magnus.hagevi@Inu.se.

Vill du läsa mer om Surveyinstitutet finns vi på internetadressen: lnu.se/surveyinstitutet

Surveyinstitutet vid Linnéuniversitetet, arbetar i enlighet med Vetenskapsrådets forskningsetiska principer (www.vr.se). Under fältarbetet ansvarar Linnéuniversitetet för att dina svar hanteras enligt personuppgiftslagen (1998:204) och behandlas så att inte obehöriga kan ta del av dem. Dina adressuppgifter har hämtats från Statens personadressregister och behövs endast så länge insamlingsarbetet pågår. De förstörs vid fältarbetets slut. När enkätsvaren har avidentifierats upphör de att vara personuppgifter och kan inte längre spåras tillbaka till någon enskild person. Enkätsvar från många personer analyseras samtidigt och resultaten presenteras i form av siffror $\mathrm{i}$ tabeller i vetenskapliga publikationer. Surveyinstitutets undersökningar kommer att förvaras vid Svensk Nationell Datatjänst (www.snd.gu.se) där de görs tillgängliga för forskning och undervisning vid universitet och högskolor. 